\title{
Exercise and bariatric surgery: A systematic review and meta-analysis of the feasibility and acceptability of exercise and controlled trial methods
}

Aurélie Baillot 1,2,3, Maxime St-Pierre ${ }^{4}$, Paquito Bernard ${ }^{5,6}$, Laura Burkhardt ${ }^{1}$, Wafaa Chorfi $^{1}$, Jean Michel Oppert ${ }^{7}$, Alice Bellicha ${ }^{8}$, Jennifer Brunet ${ }^{2,9,10}$

${ }^{1}$ Nursing Department, Université du Québec en Outaouais, Gatineau, Québec, Canada

${ }^{2}$ Institut du savoir de l'hôpital Montfort-recherche, Ottawa, Ontario, Canada

${ }^{3}$ Centre de Recherche en Médecine Psychosociale, Centre Intégré de Santé et Services Sociaux de l'Outaouais, Gatineau, Québec, Canada

${ }^{4}$ Basic science department, Université du Québec à Chicoutimi, Chicoutimi, Québec, Canada.

${ }^{5}$ Department of Physical Activity Sciences, Université du Québec à Montréal, Montréal, Québec, Canada

${ }^{6}$ Institut universitaire en santé mentale de Montréal, Montréal, Québec, Canada

${ }^{7}$ Assistance Publique-Hôpitaux de Paris (AP-HP), Pitié-Salpêtrière hospital, Department of Nutrition, Institute of Cardiometabolism and Nutrition, Sorbonne University, Paris, France

${ }^{8}$ Sorbonne Paris Nord University, Inserm U1153, Inrae U1125, Cnam, Nutritional Epidemiology Research Team (EREN), Epidemiology and Statistics Research Center University of Paris (CRESS), Bobigny, France

${ }^{9}$ Faculty of Health Sciences, School of Human Kinetics, University of Ottawa, Ottawa, Ontario, Canada 
${ }^{10}$ Cancer Therapeutic Program, Ottawa Hospital Research Institute, Ottawa, Ontario, Canada

Keywords: physical activity, obesity, dropout, adherence, compliance, lost to follow-up Running title: Exercise and bariatric surgery Address of corresponding author and e-mail address: Aurélie Baillot, Université du Québec en Outaouais, 283 Boul. Alexandre-Taché, Gatineau, Quebec, Canada, J8X 3X7. aurelie.baillot@uqo.ca

\title{
$\underline{\text { Potential conflicts of interest: None }}$
}

Funding: None

All authors are aware of and have agreed to submission to SportRxiv.

\begin{abstract}
This systematic review and meta-analysis assessed the feasibility and acceptability of exercise and controlled trial methods in adults awaiting or having undergone bariatric surgery (BS). Search methods used to identify relevant articles were: inclusion of articles identified in a systematic review, new database search of articles published 2019-21, and hand searching reference lists. Titles/abstracts and full-texts were screened by two
\end{abstract}


reviewers independently against inclusion criteria: adults awaiting or having undergone BS, controlled trial, exercise group compared to a comparison group without exercise. Twenty-eight articles were reviewed; most interventions were supervised, performed after BS, and lasted $\leq 13$ weeks. Pooled data for exercise intervention attendance and dropout rates were $84 \%(\mathrm{k}=10)$ and $5 \%(\mathrm{k}=19)$, respectively, though possibly misestimated due to poor/selective reporting. Median study and recruitment duration were 18 weeks and 24 months, respectively, with a pooled enrollment rate of 2.5 participants/month. Pooled data for refusal to participate, enrollment, and retention rates were $23 \%(\mathrm{k}=16), 43 \%(\mathrm{k}=18)$, and $87 \%(\mathrm{k}=26)$, respectively. Exercise and controlled trial methods seem feasible and acceptable for adults awaiting or having undergone BS. However, improved reporting of feasibility and acceptability indicators is needed to better identify methodological or practical challenges, and assess bias.

\section{Introduction}

The prevalence of severe obesity, defined by a body mass index $\geq 35 \mathrm{~kg} / \mathrm{m}^{2}$, is constantly increasing in higher income countries. ${ }^{1}$ Worldwide, the number of adults with obesity increased from 100 million in 1975 to 671 million in $2016 .{ }^{1}$ Severe obesity increases the risk of morbidity and mortality, and reduces quality of life. ${ }^{2-5}$ Treatment of severe obesity by bariatric surgery is generally effective for long-term weight loss, and can offer additional benefits (e.g., reduced relative risk of morbidity and mortality, improved quality 
of life) ${ }^{6,7}$ As a result, the number of bariatric surgery procedures around the world has risen dramatically in recent years, with 604,223 surgeries performed in $2018 .{ }^{8}$

Controlled trials provide evidence that exercise is an important part of care before and after bariatric surgery, as it can help to maintain or enhance the short- and long-term benefits of surgery. ${ }^{9-11}$ Previous reviews showed that exercise positively impacts cardiorespiratory fitness, muscle strength, cardiometabolic health, and weight and fat loss after bariatric surgery. ${ }^{9,11}$ However, general questions regarding the feasibility and acceptability of exercise for adults awaiting or having undergone bariatric surgery remain unanswered as previous reviews ${ }^{9-19}$ focused on summarizing the effects of exercise on outcomes of interest.

Summarizing the evidence for the feasibility and acceptability of exercise is needed for guidance of professionals and to help implementation in the field. ${ }^{20}$ In addition, this information may serve to identify potential aspects of the intervention in need of refinement during implementation. By extension, whether the methods used in controlled trials to assess the effects of exercise are both feasible and acceptable is critical as it can impact the outcomes, provide a higher level of evidence for future guideline updates, and provide a basis for selecting certain methods in future research (e.g., opt for some recruitment strategies over others). ${ }^{20}$ As well, it can help elucidate potential methodological or practical challenges warranting attention (e.g., time, resources, data management) early on during the developmental phase of the research to ensure successful trial completion. This is especially needed given the limited resources generally available.

Thus, the objective of this systematic review and meta-analysis of published controlled trials were to: i) assess the evidence of the feasibility and acceptability of exercise 
(intervention) and controlled trial methods in adults awaiting or having undergone bariatric surgery, and ii) identify factors associated with feasibility and acceptability outcomes. Whilst there are no universally accepted definitions for feasibility and acceptability adopted by authors of such controlled trials, feasibility was considered to reflect whether the exercise intervention can be delivered to participants as planned and whether the methods (e.g., assessment protocol) can be successfully executed by the researchers, ${ }^{21}$ and acceptability was considered to reflect the suitability of the exercise intervention and methods from the perspective of intended users (e.g., adults awaiting or having undergone bariatric surgery) or those responsible for implementation (e.g., healthcare providers delivering the intervention, research staff recruiting participants). ${ }^{21}$

\section{Methods}

\section{Protocol and registration}

The protocol for this systematic review and meta-analysis was registered in the Prospective Register of Systematic Reviews (PROSPERO) international registry (CRD42021255048, 07/2021) and it is reported according to the Preferred Reporting Items for Systematic Reviews and Meta-Analysis (PRISMA) guidelines. ${ }^{22}$ The completed PRISMA checklist is presented in Supplemental file 1. All supplemental files, and R data are available on Open Science Framework (https://osf.io/h4p27/).

\section{Data sources and searches}

Three search methods were used to identify relevant articles. The first method was to include all articles found in a systematic review and meta-analysis published in June 2021 
on exercise training and bariatric surgery. ${ }^{9}$ As the authors ${ }^{19}$ database search was limited to articles published prior to January 2019 , the second method was to update the database search, and search for articles published from January 1, 2019 onwards. This search was performed by two reviewers (MSP, ABa) in April 2021 using three databases: PubMed, Web of Science, and EMBASE. The search strategies for each database were developed using the same strategies as in Bellicha et al. (see Supplemental file with search strategy in Bellicha et al. ${ }^{9}$ ). "Feasibility" and "acceptability" were not added as terms to be able to retrieve as many articles as possible. The third method was to hand-search reference lists from eligible articles and relevant reviews ${ }^{10-19}$ to identify other potentially relevant articles; this search was completed by one reviewer (MSP).

\section{Eligibility criteria}

To be included, articles had to: i) be an English-language full-text article reporting on primary research published in a peer-reviewed journal; ii) involve a controlled trial, either randomized or non-randomized, comparing an exercise group to a control group without exercise, and; iii) include adults ( $\geq 18$ years) awaiting or having undergone bariatric surgery. Articles were excluded if they only presented a study focused on behavioral interventions to promote exercise engagement. Systematic reviews (with or without metaanalyses), study protocols without results, grey literature, case reports, letters/commentaries, animal studies, observational quantitative, qualitative, or mixedmethods studies, and published abstracts were also excluded.

\section{Study selection of the updated search}


Once the database searches were completed, records of the articles retrieved were imported into Endnote X9.3.3. After removing duplicates, titles and abstracts were screened concurrently against selection criteria by two reviewers (ABa, MSP). Full-texts were obtained for potentially relevant articles and screened against selection criteria by two reviewers (ABa, MSP). Where there was disagreement on eligibility, a third reviewer (JB) assessed the full-texts of the articles in detail against the selection criteria and discussions took place to determine whether the articles should be included. Next, the reference lists of the eligible articles and relevant reviews were reviewed.

\section{Data extraction}

Data pertaining to study details, participants' characteristics, exercise intervention and comparison group(s), and outcomes were extracted and entered into a Microsoft Excel table developed for this review by one reviewer (WC), and checked by two other reviewers (LB, MSP). See Supplemental file 2 for more details.

Feasibility and acceptability data were also extracted and entered into a Microsoft Excel table by one reviewer (MSP), and checked by another reviewer (ABa). Disagreements were discussed and resolved by a third reviewer (JB). To ensure a comprehensive synthesis of feasibility and acceptability evidence, the following approach was used. Data presented in the CONSORT flow chart (where applicable) were extracted for each group. Then, all data reflecting feasibility or acceptability outcomes were extracted from each article including: i) number of participants who discontinued the intervention and reasons ${ }^{1}$; ii) participants' satisfaction ratings/scores; iii) reported attendance rate related to session frequency (i.e.,

\footnotetext{
${ }^{1}$ For the purpose of this review, participants reported as having discontinued the intervention because of lack of attendance or compliance were considered as excluded from analysis.
} 
among participants analyzed, percentage of participants who attended all or a certain percentage of prescribed sessions according to the definition given by the authors of included articles ${ }^{23}$; iv) reported compliance rate related to session duration and intensity (i.e., among participants analyzed, percentage of participants who met all or a certain percentage of prescribed session duration and intensity according to the definition given by the authors of included articles) ${ }^{23}$; v) number and type of adverse events related to exercise intervention only (e.g., fall, injury), and; vi) other quantitative or qualitative data showing feasibility and acceptability of the intervention.

Additional data for feasibility and acceptability of controlled trial methods were extracted, and included: i) number of participants assessed for eligibility (i.e., number recruited); ii) number of participants excluded and reasons for exclusion (e.g., did not meet eligibility criteria, declined to participate, other reasons); iii) number of participants randomized, number of participants who refused randomization and refusal reasons; iv) number of participants allocated to each group; v) number of participants who received allocated intervention (i.e., number who started the intervention), and number of participants who did not received allocated intervention (i.e., number randomized to the intervention but did not start the intervention) and reasons; vi) number of participants lost to follow-up (i.e., number who started assessments, but did not complete them until the end of the study) and reasons $^{2}$; vii) number of participants analyzed, and number excluded from analysis and reasons; viii) recruitment strategies (description and classification into active (contact with participants was made by the research team (e.g., clinician referral, phone calls)) or passive (contact was made by potential participants (e.g., self-referral by poster, newspaper

\footnotetext{
${ }^{2}$ For the purpose of this review, participants reported as lost to follow-up because of lack of attendance were considered rather as excluded from analysis.
} 
advertisements)), ${ }^{24} \mathbf{i x}$ ) recruitment duration in months, $\mathbf{x}$ ) missing data (total (i.e., across time points and collectively for all outcomes), per time point, and/or per outcome), and xi) other quantitative or qualitative data showing feasibility and acceptability of the study protocol.

Corresponding authors were contacted two times by email to obtain missing data or clarification, if necessary. Data unavailable or unclear despite the authors responding or when authors were unresponsive after two contact attempts were marked as 'not available' (NA) or unclear (?), respectively. When multiple articles were published from a single study, only data from the first published article containing a flow chart were extracted; more recent parent articles were checked to adjust or add additional data if unavailable or unclear in the earlier article. For articles that included a follow-up phase, data were extracted separately for the intervention (i.e., from recruitment to completion of postintervention assessment) and follow-up phases (i.e., from post-intervention assessment to the end of the study) to allow for easier comparison between studies without follow-up.

\section{Quality assessment}

As in Bellicha et al.'s review, ${ }^{9}$ the quality of included articles was assessed using the National Heart, Lung and Blood Institute quality assessment tool for controlled intervention studies. ${ }^{25}$ Two reviewers $(\mathrm{ABe}, \mathrm{ABa})$ completed this task. Study quality was defined as good, fair or poor when 0,1 or $\geq 2$ fatal flaws (i.e., non-randomized study; dropout rate $>20 \%$; no intention-to-treat analyses) were identified by both reviewers. 
Disagreements were discussed between reviewers.

\section{Feasibility and acceptability data analysis}

Feasibility and acceptability data pertaining to the exercise intervention and controlled trial methods were used to calculate several rates/indicators for the intervention phase and for the follow-up phase (where applicable). Table 1 presents the calculations performed according to data extracted from the flow chart and from data in each article.

\section{Statistical analysis}

Data were grouped together to provide a tabular summary for narrative synthesis of the included articles, and where possible, quantitative data were pooled for statistical analyses. Prevalence for exercise intervention attendance and compliance, dropout, refusal to participate, recruitment, enrollment, and retention rates, as well as enrollment speed were calculated using random-effect models. Prevalence estimates were computed using the recommended Freeman-Tukey double arcsine transformation. ${ }^{26}$ For each outcome of interest, prevalence estimates were synthesized using the double arcsine transformation, and then the pooled estimate was back-transformed to a proportion. Heterogeneity was assessed with Cochran's Q and $\mathrm{I}^{2}$ statistics. A low P value (i.e., $\mathrm{p}<.10$ ) of the Q-statistic indicated that variation in the study-specific effect estimates was due to heterogeneity beyond chance. The $\mathrm{I}^{2}$ values ranging from $0 \%$ (no observed heterogeneity) to $100 \%$ (complete heterogeneity). ${ }^{27}$ The risk of publication bias was examined with funnel plots and tested using the Egger's test $\left(\mathrm{p}<.10\right.$ indicating a publication bias) ${ }^{28} \mathrm{~A}$ trim and fill analysis was also carried out to examine the impact of missing studies by adjusting the 
meta-analysis to take into account the theoretically missing studies.$^{29}$ Regression residuals were screened to identify potential multivariate outliers using residual Cook distances. Subgroup analyses (i.e., study quality, exercise intervention timing, exercise intervention duration) were carried out for each prevalence estimates. However, no comparison tests were carried out. For study quality, the median $(\mathrm{Mdn}=8)$ was used to form higher and lower quality studies $(\leq 8$ and $>8)$. For exercise intervention timing, timing was either before or after bariatric surgery. For exercise intervention duration, the median $(\mathrm{Mdn}=12)$ was used to form shorter versus longer exercise duration ( $\leq 12$ and $>12$ weeks) after excluding one study with a very long intervention duration (i.e., 100 weeks). ${ }^{30}$ All analyses were performed in R 4.1 using the 'metafor' package. ${ }^{31}$

\section{Results}

\section{Study selection}

The 31 articles from Bellicha et al.'s review ${ }^{9}$ were included (covering articles published prior to January 2019), and 725 additional articles were retrieved during the database search of articles published in January 2019 onwards after removing duplicates (Supplemental file 3). Of the latter, 10 articles met selection criteria. One additional article identified during hand-searching was reviewed; it met selection criteria, yielding a total of 42 articles representing 28 unique studies for review. Thus, $28 \operatorname{articles}^{30,32-58}$ were included after removing articles coming from the same study.

\section{Participant characteristics}

Participant characteristics for each study are described in Supplemental file 4. The 28 articles included 1,250 participants (range 6-220 per study) with a mean age $<40$ years in 
$21.4 \%(\mathrm{k}=6)$ of articles (range 33.3-53.9 years). ${ }^{34,35,42,52,54,55}$ Most $(\mathrm{k}=18,64.3 \%)$ studies had samples comprising $\geq 75 \%$ women $^{32-34,36,37,39-47,49,54,56,58}$ and $21.4 \%(\mathrm{k}=6)$ comprised only women. ${ }^{35,38,48,51-53}$ Beyond providing data on age and sex/gender, $39.3 \%(\mathrm{k}=11)$ of articles reported other sociodemographic data, ${ }^{30,32,33,35,39,44,45,49,51,52,56}$ and $42.9 \%(\mathrm{k}=12)$ reported comorbidities prevalence. ${ }^{32,33,35,36,39,46,49,51-53,56,58}$ Among the 6 articles $(21.4 \%)$

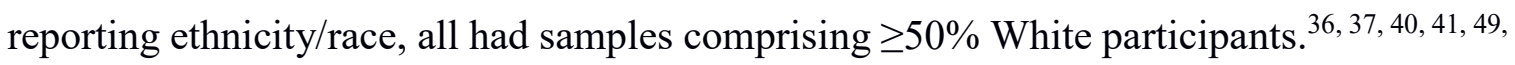
${ }^{56}$ Participants were awaiting or underwent Roux-Y gastric bypass in $32.1 \%(\mathrm{k}=9)$ of articles, ${ }^{34-36,38,45,48,50,51,53}$ sleeve gastrectomy in $7.1 \%(\mathrm{k}=2),{ }^{46,55}$ either RYGB, sleeve gastrectomy, biliopancreatic diversion with duodenal switch or gastric banding in $42.9 \%$ $(\mathrm{k}=12)^{30,33,37,39,41-44,52,56-58}$; the type of bariatric surgery was not reported in $17.9 \%(\mathrm{k}=5)$ of articles. ${ }^{32,40,46,49,54}$

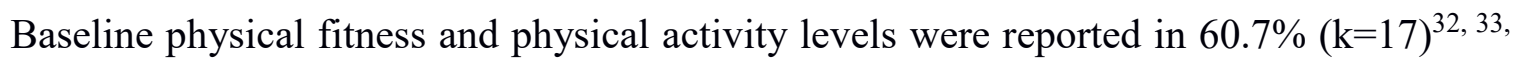
$35,37,40-43,46-49,52-54,56,57$ and $28.6 \%(\mathrm{k}=8)$ of articles, ${ }^{32,33,35,37,43,44,53,56}$ respectively. All articles including a 6-minute walking test distance $(\mathrm{k}=7,25.0 \%)^{32,33,35,37,40,49,57}$ had a mean distance ranging from 273 to $503 \mathrm{~m}$ and a mean $\mathrm{VO} 2_{\text {peak }}$ between 16 to $22 \mathrm{ml} / \mathrm{kg} / \mathrm{min}$ $(\mathrm{k}=8,28.6 \%)^{41,46-48,52,53,56,57}$ Due to the variety of measures/tools, units, and variables reported, data on baseline physical activity levels could not be synthetized. Nevertheless, data reported within articles are presented in Supplemental file 4.

\section{Exercise intervention characteristics}

Table 2 presents information on the exercise intervention and comparison groups evaluated within the 28 articles. Only data pertaining to the exercise interventions are synthesized below. A quarter $(\mathrm{k}=7)$ of interventions were initiated before bariatric surgery $32,33,40,41,46$, 49, 54; the rest $(\mathrm{k}=21,75.0 \%)$ were initiated after bariatric surgery. $30,34-39,42-45,47,48,50-53,55-$ 
${ }^{58}$ Most $(\mathrm{k}=16,57.1 \%)$ lasted $\leq 13$ weeks (range 4-104 weeks), ${ }^{32,} 33,35,38,40-46,52,55-58 \quad 89.3 \%$ $(\mathrm{k}=25)$ were supervised exercise, ${ }^{30,} 32-37,39-41,43-54,56-58$ and $35.7 \%(\mathrm{k}=10)$ held sessions individually. ${ }^{30,32,35,36,41-43,51,56,57}$ Exercise sessions were performed: in hospitals, clinics, or medical centers $(\mathrm{k}=10,35.7 \%),{ }^{33,40,43,49,51-53,56-58}$ at home $(\mathrm{k}=4,14.3 \%),{ }^{30,36,41,42}$ in research centers $(\mathrm{k}=3,10.7 \%),{ }^{35,46,47}$ in community or fitness centers $(\mathrm{k}=3,10.7 \%),{ }^{44,50,54}$ or at a facility $(\mathrm{k}=3,10.7 \%),{ }^{32,39,45}$ location was not specified in $17.9 \%(\mathrm{k}=5)$ of articles. ${ }^{34}$, $37,38,48,55$

Most $(\mathrm{k}=19,67.9 \%)$ interventions initiated after bariatric surgery started during the first year after the surgery was performed, ${ }^{30,34-39,42-44,48,50-53,55-58}$ ranging from 0 to 36 months after bariatric surgery. Only $7.1 \%(\mathrm{k}=2)$ intervention were initiated $\geq 2$ years after bariatric surgery. $^{45,} 47$ Training consisted of: endurance training $(\mathrm{k}=6,21.4 \%), 35,36,41,48,49,56$, resistance training $(\mathrm{k}=5,17.9 \%),{ }^{38,39,44,45,53}$ combination of resistance and endurance training $(\mathrm{k}=16,57.1 \%),{ }^{30,32-34,37,40,42,43,46,47,50-52,54,57,58}$ and balance training $(\mathrm{k}=1$, $3.6 \%)^{55}$

\section{Feasibility and acceptability of the interventions}

Table 2 presents information from articles on the feasibility and acceptability of the exercise intervention and comparison groups. Only data pertaining to the exercise interventions are synthetized below. Among the 57.1\% $(\mathrm{k}=16)$ of articles reporting on whether there were adverse events during exercise, ${ }^{33,35-37,39,41,43-45,48,51-54,56,58} 32.1 \%$ $(\mathrm{k}=9)$ reported none, ${ }^{36,41,43-45,51-54} 14.3 \%(\mathrm{k}=4)$ reported occasional pain, fatigue, or dyspnea, ${ }^{33,35,39,56} 7.1 \%(\mathrm{k}=2)$ reported hypoglycemia or hypotension, ${ }^{33,58}$ and $3.6 \%(\mathrm{k}=1)$ reported back bruise after a fall. ${ }^{39}$ 
Main reasons reported for exercise intervention dropout were: lack of time (12 participants from $3 \operatorname{articles}^{36,37,56}$ ), work or other commitments ( 7 participants from $2 \operatorname{articles}^{35,49}$ ), lack of motivation ( 3 participants from $1 \operatorname{article}^{48}$ ), dislike of exercise (2 participants from $1 \operatorname{article}^{35}$ ), and postponed surgery or complications (2 participants from $2 \operatorname{articles}^{43,49}$ ). Satisfaction with the exercise intervention was only reported in $3.6 \%(\mathrm{k}=1)$ of articles. ${ }^{33} \mathrm{In}$ this study, ${ }^{33}$ all participants were 'very satisfied' or 'satisfied' with the person delivering the intervention (i.e., a kinesiologist), materials, and exercise modalities, except for one participant who was 'moderately satisfied' with the evening schedule and the training location.

No meta-analysis was performed for exercise intervention compliance rate given the very small number of articles providing these data $(10.7 \%, \mathrm{k}=3)$, more importantly given the varying operationalization of compliance. ${ }^{36,56,58}$ The pooled percentage of scheduled exercise session completed (attendance) and the exercise intervention dropout rates are presented Table 3 and Supplemental file 5; related subgroup analysis are available in Table 3 and Supplemental files 6,7, and 8. Briefly, no significant differences in attendance nor dropout rates were found based on studies quality, exercise intervention timing, and exercise intervention duration.

\section{Characteristics of the controlled trial methods}

Characteristics pertaining to the methods of the controlled trials are presented in Table 4. Almost two thirds of articles $(64.3 \%, \mathrm{k}=18)$ were published in the last 5 years $(2017-21)$, with the earliest being published in 2010..$^{32,34,37-39,41-43,45-47,49-54,58}$ Most $(67.9 \%, \mathrm{k}=19)$ were randomized controlled studies. ${ }^{30,} 32,33,35-40,42,43,47,49-51,53,55,56,58$ Studies were 
conducted in Europe $(35.7 \%, \mathrm{k}=10),{ }^{30,39,43,46-48,50,53,54,57}$ North America $(32.1 \%, \mathrm{k}=9),{ }^{33}$, $36-38,40,41,44,56,58$ Brazil $(21.4 \%, \mathrm{k}=6),{ }^{34,35,45,49,51,52}$ and Iran or Turkey $(10.7 \%, \mathrm{k}=3) .{ }^{32,42 \text {, }}$ 55

Study duration per participant (excluding follow-up phase) ranged from 4 to 161 weeks; the median was 18 weeks (Table 4). Only $17.9 \%(\mathrm{k}=5)$ of studies had a follow-up phase after the exercise intervention, with a duration ranging from 9 to 52 weeks. $^{33,43,47,50,58}$ Most $(85.7 \%, \mathrm{k}=6)$ studies in which the exercise intervention was delivered before bariatric

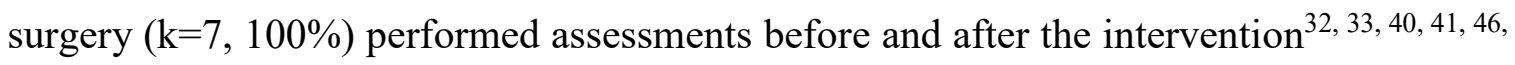
49, 54; the other $(14.3 \%, \mathrm{k}=1)$ performed assessments before, during, and after the intervention. ${ }^{54}$ Among the $21(100 \%)$ studies in which the exercise intervention was

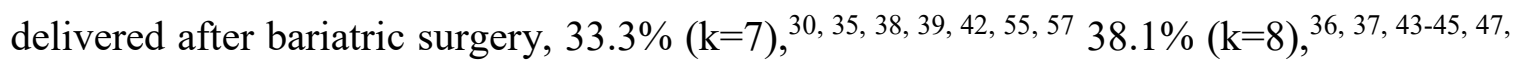
48, 56 and $28.6 \%(\mathrm{k}=6)^{34,50-53,58}$ performed baseline assessments before bariatric surgery, before the exercise intervention (i.e., after bariatric surgery), or at both these times, respectively. The number of assessments (excluding the follow-up phase) ranged from 2 to 9, with $17.9 \%(\mathrm{k}=5)$ having $\geq 3$ assessments. ${ }^{30,34,39,47,53}$

\section{Feasibility and acceptability of the controlled trial methods}

Data pertaining to the feasibility and acceptability of the controlled trial methods are presented Table 4. Among the $46.4 \%(\mathrm{k}=13)$ of articles reporting recruitment duration, ${ }^{32}$, $33,35,36,39,41-43,50,53,58$ the median duration was 24 months (ranged from 6-56 months).

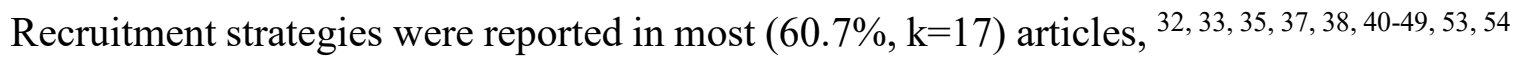
among these, active, passive, or mixed approaches were used in $70.6 \%(\mathrm{k}=12), 32,35,37,40$, $42,43,46-49,53,5417.6 \%(\mathrm{k}=3),{ }^{38,44,45}$ and $11.8 \%(\mathrm{k}=2)^{33,41}$ studies, respectively. For studies 
in which the exercise intervention was delivered after bariatric surgery, $66.7 \%(\mathrm{k}=14)$ recruited participant before bariatric surgery. ${ }^{30,34,35,38,39,42,47,50-53,55,57,58}$

The reasons for lost to follow-up for the exercise groups were: lack of time and commitment issues (21 participants from 6 articles), ${ }^{35,36,39,48,56,57}$ surgery-related issues (14 participants from 5 articles), ${ }^{33,34,49,51,58}$ and unreachable ( 9 participants from 2 articles) (Table 4). ${ }^{37,39}$

Among the 28 articles, $17.9 \%(\mathrm{k}=5)^{33,39,41,51,53}$ reported some missing data by outcomes and/or time-points, and $10.7 \%(\mathrm{k}=3)^{36,43,50}$ described the method used to handle missing data.

Pooled data for refusal to participate, recruitment, enrollment, and retention rates, and enrollment speed are presented in Table 3 and Supplemental file 5. Related subgroup analyses are available in Table 3 and Supplemental files 6,7, and 8; no significant differences were found based on study quality, exercise intervention timing, and exercise intervention duration. Randomization refusal rate was not pooled due to the high number of studies without dropout because of dissatisfaction with group allocation (only 4 studies including 8 participants who refused randomization). ${ }^{33,43,56,58}$

\section{Studies quality}

Study quality was rated as good, fair, and poor for $28.6 \%(\mathrm{k}=8),{ }^{33,36-38,43,50,51,53} 35.7 \%$ $(\mathrm{k}=10),{ }^{30,32,39,40,42,44,47,49,52,56}$ and $35.7 \%(\mathrm{k}=10)$ of articles, ${ }^{34,35,41,45,46,48,54,55,57,58}$ respectively (Supplemental file 9). Informing these scores, is that most $(67.9 \%, \mathrm{k}=19)$ articles presented a randomized study, ${ }^{30,32,33,35-40,42,43,47,49-51,53,55,56,58} 46.4 \%$ ( $\left.\mathrm{k}=13\right)$ reported a dropout rate $<20 \%, 30,32,33,36-38,42-44,47,50,52,53$ and $53.6 \%(\mathrm{k}=15)$ reported intention-to-treat analyses. ${ }^{33,36-40,43,44,46,49-53,56} \mathrm{~A}$ third or less of articles reported blinding 
for outcomes $(10.7 \%, \mathrm{k}=3)^{32,36,49}$ and treatment assignment $(0 \%, \mathrm{k}=0)$, "high attendance rate" (i.e. participation to exercise training sessions $\geq 70 \%$ or proportion of completers $\geq 70$ \%) $(\mathrm{k}=10,35.7 \%)^{30,35,41,43-45,47,49,51,54}$, and sample size justification $(35.7 \%, \mathrm{k}=10) .{ }^{32,35 \text {, }}$ $39,42,43,45,47,50,51,53$

\section{Discussion}

\section{Summary of evidence}

Systematic reviews have summarized evidence on the effects of exercise intervention before and after bariatric surgery. ${ }^{9-19}$ To complement these reviews and make recommendations for practice and future research, the present systematic review summarized evidence on the acceptability and feasibility of exercise interventions and controlled trial methods in adults awaiting or having undergone bariatric surgery.

Overall, available data from 28 articles reviewed show that exercise intervention compliance is very seldom reported $(10.7 \%, \mathrm{k}=3)$, the mean rate for exercise intervention attendance is $84 \%$ (based on data available from $28.6 \%(\mathrm{k}=8)$ of articles), and the mean exercise intervention dropout rate is $5 \%$ (based on data available from $64.3 \%(\mathrm{k}=18)$ of articles). In addition, most adverse events reported noted in the $57.1 \%(\mathrm{k}=16)$ were relatively minor. Collectively, these indicators suggest that exercise interventions can be feasible and acceptable before and after bariatric surgery, but the relative lack of data available prevents us from making firm conclusions.

Although no consensus exists, attending $\geq 70 \%$ of sessions is often mentioned as "high" for exercise intervention. ${ }^{59}$ With a pooled mean of $84 \%$ [95\%CI: $77-91 \%$ ] of sessions completed, the attendance rate calculated could be considered as high, which is important 
because attendance rate can impact study results. ${ }^{59,60}$ This rate is broadly similar to reported rates for people with type 2 diabetes $(68-100 \%)^{61}$ and cancer $(70-98 \%){ }^{62}$ However, these findings must be interpreted with caution. Session attendance was not reported in $39.3 \%(\mathrm{k}=11)$ of included articles (see Table 2), which could overestimate the calculated pooled attendance rate mean, especially if studies with lower attendance were less likely to report these data. As well, session attendance was calculated/reported differently across articles (e.g., $\%$ of participants who attended all exercise sessions, $\%$ of participants who attended a certain number of exercise sessions). In addition, exercise intervention attendance rate, which relates to frequency, is only one aspect of exercise intervention adherence. Suppose two participants attended all scheduled sessions $(100 \%$ attendance), but only one completed the prescribed 30-minute aerobic training at moderate intensity. Focusing solely on attendance can be very misleading if suitable attention is not also given to compliance to the prescribed exercise dosage, which relates to duration and intensity. ${ }^{23}$ Authors should give more attention to collecting and reporting data that reflect several key characteristics relating to exercise intervention adherence for transparency and help (potentially) explain lack of efficacity of exercise training. ${ }^{60}$

Across 19 exercise groups, the exercise intervention dropout rate was $5 \%$, which is lower than rates observed in adults with depression $(15 \%),{ }^{63}$ type 2 diabetes $(<20 \%),{ }^{61}$ and advanced cancer $(24 \%) .{ }^{64}$ The lower rate herein could be explained by the population. Speculatively, adults awaiting or having undergone bariatric surgery may be highly motivated to exercise because of their fear of regaining weight and/or because they receive support via regular medical and nutritional follow-ups. The lower rate could also be explained by the small number of articles that reported this information $(64.3 \%, \mathrm{k}=18)$, 
whereby those with higher dropout rate may not have reported these data. Last, it could be because we considered exercise intervention dropout only (not study or follow-up dropout). In other words, participants who completed the intervention, but did not come to the last assessment were not consider in the calculation of the exercise intervention dropout rate. Nevertheless, lack of time, work or other commitments, and lack of motivation were among the main reasons for exercise dropout among the $32.1 \%(\mathrm{k}=9)$ articles reporting reasons when they had dropouts. These reasons reflect key barriers to physical activity in adults with obesity. ${ }^{65}$ and underscore the need to develop strategies to enhance motivation and perhaps offer alternative means for those lacking time or with competing commitments (e.g., online interventions) to reduce dropout and maximize intervention success.

Concerning feasibility and acceptability of controlled trial methods in adults awaiting or having undergone bariatric surgery, results suggest several months (median 24 months (range 6-56 months)) are required to recruit 6 to 220 participants (based on the $46.4 \%$ $(\mathrm{k}=13)$ articles reporting these data). With a pooled mean of 7 participants assessed for eligibility per month ( $23 \%$ of refusal to participate rate) and 2.5 participants enrolled per month, the pooled enrollment rate was $43 \%$. Recruitment is one of the most challenging steps in research with clinical populations, requiring significant commitment from staff and resources to reach target sample size. ${ }^{24}$ As adverse scientific, economic, and ethical impacts can occur with prolonged or inefficient recruitment, ${ }^{66,67}$ multicenter recruitment, patient involvement, and hiring of qualified staff should be considered to optimize recruitment. As well, recruitment strategies should be chosen carefully during the planning phase and reported during the dissemination phase to help others evaluate whether 
strategies used were effective. ${ }^{24}$ Based on available data reported, active recruitment strategies were used most $(70.6 \%, \mathrm{k}=12)$, followed by passive strategies alone $(17.6 \%$, $\mathrm{k}=3$ ), and a mix of active and passive strategies $(11.8 \%, \mathrm{k}=2)$. Active methods of recruitment seem to result in better recruitment, population representativity, and retention than passive methods, but these are more expensive. ${ }^{68}$ This said, the recruitment process was often poorly described or not described at all $(39.3 \%, \mathrm{k}=11)$, making it impossible to determine the most cost-effectiveness strategy/ies for recruiting adults awaiting or having undergone bariatric surgery into exercise trials. Regardless, integrating clinical staff can be helpful for recruitment within the scheduled time frame in bariatric surgery studies ${ }^{69}$; so effective partnerships should be created.

Retention rates for the exercise intervention ( $87 \%$ [95\%CI: $80-93 \%$ ]; $\mathrm{k}=26)$ and comparison groups ( $87 \%$ [95\%CI: $81-92 \%]$; $\mathrm{k}=26)$, as well as randomisation refusal rate (only 8 participants across 4 studies) were good, suggesting the employed methods in the controlled trial methods were feasible and acceptable to participants. There is consensus that retention rates $\geq 80 \%$ are "acceptable" and that such rates help to minimize internal, external, and statistical validity threats. ${ }^{70}$ The good pooled retention rate could be explained by the short study duration for participants (median 18 weeks) and small number of assessments ( 2 or 3 assessments), which are known factors affecting retention. ${ }^{71}$ On the other hand, having supervised exercise sessions $(89.3 \%, \mathrm{k}=25)$ required frequent in-person visits, which could have affected enrollment in the first place (i.e., before the intervention/study has started), whereby those who foresaw barriers related to the intervention/study could have refused to participate, resulting in selection bias but good retention rates. This is a serious problem because many adults who might profit from an 
exercise intervention may not be included in controlled trials. It is important that we know more about the causes of non-participation and study drop-out, regardless of rates, so as to enable reliable evaluations of exercise interventions and generalization of the results. Thus, authors should provide information about participants versus non-participants, as well as completers and non-completers. As for retention strategies, some guidance is available from the Longitudinal Assessment of Bariatric Surgery study ${ }^{72}$ and the Behavior Change Consortium. ${ }^{73}$ Potential strategies include flexible schedule, incentives reimbursements, shortening visit length and number, coupling medical to research visits, and participant bonding or identification with the study, though it remains to be seen which strategy (or strategies) is most effective.

To explore factors influencing feasibility and acceptability indicators, as well as heterogeneity, subgroup analyses were performed; no significant differences were noted based on study quality, exercise intervention timing, and intervention duration. The absence of significant differences could be explained by the lack of statistical power herein since subgroup analyses require many more included studies than are needed for the main analyses of the meta-analysis. ${ }^{74}$ The number of sub analysis initially planned (population, intervention and methodology-related characteristics) for this meta-analysis was greatly reduced due to the small number of studies and data available.

\section{Strengths and limitations of this review}

The systematic analysis of the peer-reviewed literature is the main strength of this review. Indeed, the articles identified were the result of an extensive search in different databases, and screening and data extraction were conducted by multiple reviewers to minimize bias. 
However, some limitations should be considered when interpreting the results. First, this review contains articles stemming from controlled trials published in peer-reviewed journals with full-texts available in English only. Second, the characteristics of the included articles limits the ability to generalize results. For example, $68 \%(\mathrm{k}=19)$ of studies were completed in higher income countries, and sociodemographic data were missing in $68 \%$ $(\mathrm{k}=19)$ of articles. Moreover, men were largely underrepresented. Third, studies were not necessarily designed to explore the feasibility or acceptability of an exercise intervention and/or controlled trial methods, limiting collection of (or reporting) of some data relating to feasibility and acceptability (e.g. satisfaction rate). Fourth, data extraction and interpretation were challenging due to the absence of clear definitions and a lack of consensus on the concepts of "feasibility" and "acceptability," though the CONSORT flow chart presented in most $(60.7 \%, \mathrm{k}=17)$ articles aided. Finally, publication bias could also affect the findings.

\section{Recommendations for exercise intervention implementation, research, and reporting}

When interpreting exercise intervention adherence and dropout rates in bariatric surgery population, persons planning to implement exercise interventions should keep in mind the impact of selection bias across included studies due to voluntary basis recruitment and specific selection criteria leading to probable over estimation of the adherence rate and

under estimation of the dropout rate. ${ }^{59}$ Based on the voluntary basis, and selection criteria of some studies, it is likely that adults who had a higher disease burden, poorer functional status and motivation were not included, providing only a partial view of what happens in real life conditions; these trials may not address the feasibility and acceptability of exercise 
for a subgroup of adults awaiting or having undergone bariatric surgery. Researchers are encouraged to include these adults to examine the effects (as well as the adverse effects) that may result. Relatedly, the lack of data on non-participants raises the possibility that issues of feasibility and acceptability may come about even before participants enroll into trials. Thus, researchers will need to consider how possible differences are likely to impact on the results, as this will influence the certainty of evidence. In addition, the acceptability and feasibility of exercise training in people awaiting or having undergone bariatric surgery may be affected by type of exercise; yet, there was limited variety across studies. Many studies focused on walk, treadmill, or ergocycle (for endurance/aerobic training) or machines or small equipment (for resistance training). Only one study focused on running after bariatric surgery ${ }^{48}$ and another on aquatic training before bariatric surgery ${ }^{40}$. Further investigation into the feasibility and acceptability of different type of exercise is warranted, and whether it matters if it is the researchers who chose the type of exercise or the participants. Because patient-oriented strategies can increase participation and adherence as patients feel included in their decisions, ${ }^{75-78}$ and because adults mostly get to choose their own type of exercise in real life, examining whether integrating participants' preferences into interventions improves feasibility and acceptability seems valuable. Also, to reach larger proportion of bariatric surgery patients, several modalities of intervention (e.g. in person, telehealth, individual or group) and setting (hospital, community) should be considered for implementation. Last, based on identified gaps, future studies are necessary to draw conclusions regarding the feasibility and acceptability of multicentric study, long-term data collection (follow-up period after the intervention), exercise intervention in male and visible minorities. 
As more research is conducted, the most critical points to address in included articles are the clarity and transparency in reporting feasibility and acceptability data. The major recommendation coming out of this review is that future studies should report consistently these data to better identify which exercise intervention offer the most promising results in terms of efficacy and implementation. The systematic use of the PRISMA flow chart could help in this direction. To increase transparency, researchers should too describe missing data by outcome, by time-point and by group (number and reason), and how missing data were handled. ${ }^{79}$ Also, previous and future trials should systematically share their raw data. It facilitates the development of individual patient data meta-analysis (in exercise, e.g., $\left.\mathrm{see}^{80}\right)$. This method is particularly recommended to study moderators of intervention effects. ${ }^{81}$ For instance, it allows to disentangle subject-level and study-level sources of heterogeneity in adherence rates. Better reports of feasibility and acceptability data could also help future meta-analysis to identify factors associated with better adherence, recruitment, enrollment and retention.

\section{Conclusion}

Despite the present lack of data available in controlled trials included, exercise intervention and controlled trial methods in adults awaiting or having undergone bariatric surgery seem to be feasible and acceptable, though there is room for improvement. To improve evidencebased knowledge, identify methodological and practical challenges and bias, better reporting of adherence, dropout, adverse events, recruitment, enrollment, retention data, and strategies used are needed in future controlled trials. This should help implement exercise training protocols in real life conditions that will be specifically adapted to clinical care in the setting of bariatric surgery. 


\section{References}

1 Worldwide trends in body-mass index, underweight, overweight, and obesity from 1975 to 2016: a pooled analysis of 2416 population-based measurement studies in 128.9 million children, adolescents, and adults. Lancet. 2017; 390: 2627-42.

2 Must A, Spadano J, Coakley EH, et al. The disease burden associated with overweight and obesity. JAMA. 1999; 282: 1523-9.

3 Chang SH, Pollack LM, Colditz GA. Life Years Lost Associated with ObesityRelated Diseases for U.S. Non-Smoking Adults. PloS one. 2013; 8: e66550.

$4 \quad$ Flegal KM, Graubard BI, Williamson DF, Gail MH. Cause-specific excess deaths associated with underweight, overweight, and obesity. JAMA. 2007; 298: 2028-37.

5 Taylor VH, Forhan M, Vigod SN, McIntyre RS, Morrison KM. The impact of obesity on quality of life. Best Pract Res Clin Endocrinol Metab. 2013; 27: 139-46.

6 Arterburn DE, Telem DA, Kushner RF, Courcoulas AP. Benefits and Risks of Bariatric Surgery in Adults: A Review. JAMA. 2020; 324: 879-87. 
7 Wiggins T, Guidozzi N, Welbourn R, Ahmed AR, Markar SR. Association of bariatric surgery with all-cause mortality and incidence of obesity-related disease at a population level: A systematic review and meta-analysis. PLoS Med. 2020; 17: e1003206. 8 Angrisani L, Santonicola A, Iovino P, et al. Bariatric surgery survey 2018: similarities and disparities among the 5 IFSO chapters. Obes Surg. 2021; 31: 1937-48.

9 Bellicha A, van Baak MA, Battista F, et al. Effect of exercise training before and after bariatric surgery: A systematic review and meta-analysis. Obes Rev. 2021; 22 Suppl 4: e13296.

10 Baillot A, Audet M, Baillargeon JP, et al. Impact of physical activity and fitness in class II and III obese individuals: a systematic review. Obes Rev. 2014; 15: 721-39.

11 Carretero-Ruiz A, Martínez-Rosales E, Cavero-Redondo I, et al. Impact of exercise training after bariatric surgery on cardiometabolic risk factors: a systematic review and meta-analysis of controlled trials. Rev Endocr Metab Disord. 2021: 1-22.

12 Bellicha A, Ciangura C, Poitou C, Portero P, Oppert JM. Effectiveness of exercise training after bariatric surgery-a systematic literature review and meta-analysis. Obes Rev. 2018; 19: 1544-56.

13 Carretero-Ruiz A, Olvera-Porcel MDC, Cavero-Redondo I, et al. Effects of Exercise Training on Weight Loss in Patients Who Have Undergone Bariatric Surgery: a Systematic Review and Meta-Analysis of Controlled Trials. Obes Surg. 2019; 29: 337184.

14 Civi Karaaslan T, Leblebici G, Ucgul MS, et al. Exercise Program in Patients After Bariatric Surgery: A Systematic Review. Bariatr Surg Pract Patient Care. 2020; 15: 3-10. 15 da Silva AL, Sardeli AV, André LD, et al. Exercise training does improve cardiorespiratory fitness in post-bariatric surgery patients. Obes Surg. 2019; 29: 1416-19. 16 Fonseca H, Oliveira J. Have We Disregarded Resistance Exercise for the Prevention of Postbariatric Surgery Weight and Comorbidities Relapse? Obesity. 2020; 28: 2255-56.

17 Hansen D, Decroix L, Devos Y, et al. Towards optimized care after bariatric surgery by physical activity and exercise intervention: a review. Obes Surg. 2020; 30: $1118-25$.

18 Morales-Marroquin E, Kohl HW, Knell G, de la Cruz-Muñoz N, Messiah SE. Resistance training in post-metabolic and bariatric surgery patients: a systematic review. Obes Surg. 2020: 1-10.

19 Ren Z-Q, Lu G-D, Zhang T-Z, Xu Q. Effect of physical exercise on weight loss and physical function following bariatric surgery: a meta-analysis of randomised controlled trials. BMJ open. 2018; 8: $\mathrm{e} 023208$.

20 Skivington K, Matthews L, Simpson SA, et al. A new framework for developing and evaluating complex interventions: update of Medical Research Council guidance. BMJ. 2021; 374: n2061.

21 Feeley N, Cossette S, Cote J, et al. The importance of piloting an RCT intervention. Can J Nurs Res. 2009; 41: 85-99.

22 Liberati A, Altman DG, Tetzlaff J, et al. The PRISMA statement for reporting systematic reviews and meta-analyses of studies that evaluate health care interventions: explanation and elaboration. J Clin Epidemiol. 2009; 62: e1-e34. 
23 Kampshoff CS, van Mechelen W, Schep G, et al. Participation in and adherence to physical exercise after completion of primary cancer treatment. Int J Behav Nutr Phys Act. 2016; 13: 100.

24 Foster CE, Brennan G, Matthews A, et al. Recruiting participants to walking intervention studies: a systematic review. Int J Behav Nutr Phys Act. 2011; 8: 137.

25 Jensen MD, Ryan DH, Apovian CM, et al. 2013 AHA/ACC/TOS guideline for the management of overweight and obesity in adults: a report of the American College of Cardiology/American Heart Association Task Force on Practice Guidelines and The Obesity Society. Circulation. 2014; 129: S102-38.

26 Barendregt JJ, Doi SA, Lee YY, Norman RE, Vos T. Meta-analysis of prevalence. J Epidemiol Community Health. 2013; 67: 974-8.

27 Higgins JP, Thompson SG, Deeks JJ, Altman DG. Measuring inconsistency in meta-analyses. $B M J .2003 ; 327: 557-60$.

28 Egger M, Davey Smith G, Schneider M, Minder C. Bias in meta-analysis detected by a simple, graphical test. BMJ. 1997; 315: 629-34.

29 Rothstein HR, Sutton AJ, Borenstein M. Publication bias in meta-analysis: Prevention, assessment and adjustments: John Wiley \& Sons 2006.

30 Muschitz C, Kocijan R, Haschka J, et al. The impact of vitamin D, calcium, protein supplementation, and physical exercise on bone metabolism after bariatric surgery: the BABS study. J Bone Miner Res. 2016; 31: 672-82.

31 Viechtbauer W. Conducting Meta-Analyses in R with the metafor Package. J Stat Softw. 2010; 36: 1 - 48.

32 Arman N, Tokgoz G, Seyit H, Karabulut M. The effects of core stabilization exercise program in obese people awaiting bariatric surgery: A randomized controlled study. Complement Ther Clin Pract. 2021; 43: 101342.

33 Baillot A, Mampuya WM, Dionne IJ, et al. Impacts of supervised exercise training in addition to interdisciplinary lifestyle management in subjects awaiting bariatric surgery: a randomized controlled study. Obes Surg. 2016; 26: 2602-10.

34 Campanha-Versiani L, Pereira DAG, Ribeiro-Samora GA, et al. The effect of a muscle weight-bearing and aerobic exercise program on the body composition, muscular strength, biochemical markers, and bone mass of obese patients who have undergone gastric bypass surgery. Obes Surg. 2017; 27: 2129-37.

35 Castello V, Simoes RP, Bassi D, et al. Impact of aerobic exercise training on heart rate variability and functional capacity in obese women after gastric bypass surgery. Obes Surg. 2011; 21: 1739-49.

36 Coen PM, Tanner CJ, Helbling NL, et al. Clinical trial demonstrates exercise following bariatric surgery improves insulin sensitivity. J Clin Invest. 2015; 125: 248-57.

37 Coleman KJ, Caparosa SL, Nichols JF, et al. Understanding the capacity for exercise in post-bariatric patients. Obes Surg. 2017; 27: 51-58.

38 Daniels P, Burns RD, Brusseau TA, et al. Effect of a randomised 12-week resistance training programme on muscular strength, cross-sectional area and muscle quality in women having undergone Roux-en-Y gastric bypass. J Sports Sci. 2018; 36: 52935 .

39 Diniz-Sousa F, Veras L, Boppre G, et al. The effect of an exercise intervention program on bone health after bariatric surgery: a randomized controlled trial. $J$ Bone Miner Res. 2021; 36: 489-99. 
40 Funderburk JA, \& Callis, S. Aquatic intervention effect on quality of life. prior to obesity surgery: A pilot study. Annu Ther Recreation. 2010; 18: 66-78.

41 Gilbertson NM, Gaitán JM, Osinski V, et al. Pre-operative aerobic exercise on metabolic health and surgical outcomes in patients receiving bariatric surgery: A pilot trial. PloS one. 2020; 15: e0239130.

42 Hassannejad A, Khalaj A, Mansournia MA, Tabesh MR, Alizadeh Z. The effect of aerobic or aerobic-strength exercise on body composition and functional capacity in patients with BMI $\geq 35$ after bariatric surgery: a randomized control trial. Obes Surg. 2017; 27: 2792-801.

43 Herring LY, Stevinson C, Carter P, et al. The effects of supervised exercise training 12-24 months after bariatric surgery on physical function and body composition: a randomised controlled trial. Int J Obes (Lond). 2017; 41: 909-16.

44 Huck CJ. Effects of supervised resistance training on fitness and functional strength in patients succeeding bariatric surgery. J Strength Cond Res. 2015; 29: 589-95.

45 Lamarca F, Vieira FT, Lima RM, et al. Effects of resistance training with or without protein supplementation on body composition and resting energy expenditure in patients 2-7 years postRoux-en-Y gastric bypass: a controlled clinical trial. Obes Surg. 2021; 31: $1635-46$.

46 Marc-Hernández A, Ruiz-Tovar J, Aracil A, Guillén S, Moya-Ramón M. Impact of exercise on body composition and cardiometabolic risk factors in patients awaiting bariatric surgery. Obes Surg. 2019; 29: 3891-900.

47 Marc-Hernández A, Ruiz-Tovar J, Aracil A, Guillén S, Moya-Ramón M. Effects of a high-intensity exercise program on weight regain and cardio-metabolic profile after 3 years of bariatric surgery: a randomized trial. Scientific reports. 2020; 10: 1-10.

48 Marchesi F, De Sario G, Reggiani V, et al. Road running after gastric bypass for morbid obesity: rationale and results of a new protocol. Obes Surg. 2015; 25: 1162-70.

49 Marcon ER, Baglioni S, Bittencourt L, et al. What is the best treatment before bariatric surgery? Exercise, exercise and group therapy, or conventional waiting: a randomized controlled trial. Obes Surg. 2017; 27: 763-73.

50 Mundbjerg LH, Stolberg CR, Cecere S, et al. Supervised physical training improves weight loss after roux-en-Y gastric bypass surgery: a randomized controlled trial. Obesity. 2018; 26: 828-37.

51 Murai IH, Roschel H, Dantas WS, et al. Exercise mitigates bone loss in women with severe obesity after Roux-en-Y gastric bypass: a randomized controlled trial. J Clin Endocrinol Metab. 2019; 104: 4639-50.

52 Onofre $\mathrm{T}$, Carlos $\mathrm{R}$, Oliver $\mathrm{N}$, et al. Effects of a physical activity program on cardiorespiratory fitness and pulmonary function in obese women after bariatric surgery: a pilot study. Obes Surg. 2017; 27: 2026-33.

53 Oppert JM, Bellicha A, Roda C, et al. Resistance training and protein supplementation increase strength after bariatric surgery: a randomized controlled trial. Obesity. 2018; 26: 1709-20.

54 Picó-Sirvent I, Aracil-Marco A, Pastor D, Moya-Ramón M. Effects of a combined high-intensity interval training and resistance training program in patients awaiting bariatric surgery: a pilot study. Sports. 2019; 7: 72. 
55 Rojhani-Shirazi Z, Mansoriyan SA, Hosseini S. The effect of balance training on clinical balance performance in obese patients aged 20-50 years old undergoing sleeve gastrectomy. Eur Surg. 2016; 48: 105-09.

56 Shah M, Snell PG, Rao S, et al. High-volume exercise program in obese bariatric surgery patients: a randomized, controlled trial. Obesity. 2011; 19: 1826-34.

57 Stegen S, Derave W, Calders P, Van Laethem C, Pattyn P. Physical fitness in morbidly obese patients: effect of gastric bypass surgery and exercise training. Obes Surg. 2011; 21: 61-70.

58 Tardif I, Auclair A, Piché M-E, et al. Impact of a 12-week randomized exercise training program on lipid profile in severely obese patients following bariatric surgery. Obes Surg. 2020; 30: 3030-36.

59 Nagpal TS, Mottola MF, Barakat R, Prapavessis H. Adherence is a key factor for interpreting the results of exercise interventions. Physiotherapy. 2021; 113: 8-11.

60 Willinger N, Steele J, Atkinson L, et al. Effectiveness of Structured Physical Activity Interventions Through the Evaluation of Physical Activity Levels, Adoption, Retention, Maintenance, and Adherence Rates: A Systematic Review and Meta-Analysis. J Phys Act Health. 2021; 18: 116-29.

61 Umpierre D, Ribeiro PA, Kramer CK, et al. Physical activity advice only or structured exercise training and association with HbA1c levels in type 2 diabetes: a systematic review and meta-analysis. JAMA. 2011; 305: 1790-9.

62 Turner RR, Steed L, Quirk H, et al. Interventions for promoting habitual exercise in people living with and beyond cancer. Cochrane Database Syst Rev. 2018.

63 Stubbs B, Vancampfort D, Rosenbaum S, et al. Dropout from exercise randomized controlled trials among people with depression: A meta-analysis and meta regression. $J$ Affect Disord. 2016; 190: 457-66.

64 Sheill G, Guinan E, Brady L, Hevey D, Hussey J. Exercise interventions for patients with advanced cancer: A systematic review of recruitment, attrition, and exercise adherence rates. Palliat Support Care. 2019; 17: 686-96.

65 Baillot A, Chenail S, Barros Polita N, et al. Physical activity motives, barriers, and preferences in people with obesity: A systematic review. PloS one. 2021; 16: e0253114.

66 Gross D, Fogg L. Clinical trials in the 21st century: the case for participant-centered research. Res Nurs Health. 2001; 24: 530-9.

67 Watson JM, Torgerson DJ. Increasing recruitment to randomised trials: a review of randomised controlled trials. BMC Med Res Methodol. 2006; 6: 34.

68 Gul RB, Ali PA. Clinical trials: the challenge of recruitment and retention of participants. J Clin Nurs. 2010; 19: 227-33.

69 Paramasivan S, Rogers CA, Welbourn R, et al. Enabling recruitment success in bariatric surgical trials: pilot phase of the By-Band-Sleeve study. Int J Obes (Lond). 2017; 41: 1654-61.

70 Fewtrell MS, Kennedy K, Singhal A, et al. How much loss to follow-up is acceptable in long-term randomised trials and prospective studies? Arch Dis Child. 2008; 93: 458-61.

71 Grill JD, Karlawish J. Addressing the challenges to successful recruitment and retention in Alzheimer's disease clinical trials. Alzheimers Res Ther. 2010; 2: 34. 
72 Gourash WF, Ebel F, Lancaster K, et al. Longitudinal Assessment of Bariatric Surgery (LABS): retention strategy and results at 24 months. Surg Obes Relat Dis. 2013; 9: 514-9.

73 Coday M, Boutin-Foster C, Goldman Sher T, et al. Strategies for retaining study participants in behavioral intervention trials: retention experiences of the NIH Behavior Change Consortium. Ann Behav Med. 2005; 29 Suppl: 55-65.

74 Cuijpers P, Griffin JW, Furukawa TA. The lack of statistical power of subgroup analyses in meta-analyses: a cautionary note. Epidemiol Psychiatr Sci. 2021; 30: e78.

75 Williams DM, Dunsiger S, Miranda Jr R, et al. Recommending self-paced exercise among overweight and obese adults: a randomized pilot study. Ann Behav Med. 2015; 49: $280-85$.

76 Williams DM. Exercise, affect, and adherence: an integrated model and a case for self-paced exercise. J Sport Exerc Psychol. 2008; 30: 471.

77 Joosten EA, DeFuentes-Merillas L, De Weert G, et al. Systematic review of the effects of shared decision-making on patient satisfaction, treatment adherence and health status. Psychother psychosom. 2008; 77: 219-26.

78 Parfitt G, Rose EA, Burgess WM. The psychological and physiological responses of sedentary individuals to prescribed and preferred intensity exercise. Br J Health Psychol. 2006; 11: 39-53.

79 Akl EA, Kahale LA, Ebrahim S, et al. Three challenges described for identifying participants with missing data in trials reports, and potential solutions suggested to systematic reviewers. J Clin Epidemiol. 2016; 76: 147-54.

80 Bernard P, Savard J, Steindorf K, et al. Effects and moderators of exercise on sleep in adults with cancer: Individual patient data and aggregated meta-analyses. $J$ Psychosom Res. 2019; 124: 109746.

81 Ioannidis J. Next-generation systematic reviews: prospective meta-analysis, individual-level data, networks and umbrella reviews. Br J Sports Med. 2017; 51: 145658. 
Table 1. Feasibility and acceptability data analysis

Table 2. Description, feasibility and acceptability of interventions delivered before and after bariatric surgery among studies included $(\mathrm{k}=28)$

Data are presented as mean $\pm \mathrm{SD}$ or median $\left(25^{\text {th }}-75^{\text {th }}\right.$ percentiles $)$

$\mathrm{ACT}=$ aerobic continuous training; $\mathrm{BS}=$ bariatric surgery; HIIT $=$ high-intensity interval training; $\mathrm{HR}=$ heart rate; $\mathrm{HRR}=$ heart rate reserve; $\mathrm{PA}=$ physical activity; $\mathrm{NA}=$ not available; OMINI-RES = OMNIResistance Exercise Scale; reps = repetitions; RPE = rating of perceived exertion; RPM = one repetition maximum; VAT-RCP = difference between ventilator anaerobic threshold and respiratory compensation point; wk. $=$ week(s)

*Session duration included warm-up and cool down duration; **Drop out rate $=\%$ of participants who discontinued intervention

Table 3. Pooled percentage of feasibility and acceptability indicators of exercise and controlled trial methods in adults awaiting or having undergone bariatric surgery

Study quality and intervention duration subgroup analyses are based on median; Studies considered high quality $=$ score $>8 / 14$ and low quality $=$ score $\leq 8 / 14$; Longer intervention duration $=>12$ weeks excluding studies with $>100$ weeks of intervention duration and shorter duration $\leq 12$ weeks. BS $=$ bariatric surgery. Randomization refusal rate (\%) was not pooled due to the high number of 0 among studies (only 4 studies including 8 participants who refused randomization).

Table 4. Description, feasibility and acceptability of controlled trial methods in bariatric surgery population among studies included $(\mathrm{k}=28)$

* = except sociodemographic data; $\mathrm{BS}=$ bariatric surgery; $\mathrm{CBT}=$ cognitive-behavioral therapy; $\mathrm{QE}=$ quasiexperimental study; NA = not available; MMTT = Mixed meal tolerance test; PA = physical activity; REE = Resting energy expenditure; $\mathrm{RCT}=$ randomized controlled study. ${ }^{\mathrm{S}}=$ outcomes self-reported; ${ }^{\mathrm{O}}=$ outcomes objectively assessed.

Supplemental file 1. Prisma 2020 checklist

Supplemental file 2. Study details, participants' characteristics, exercise intervention and comparison group(s), and outcomes extracted and entered into a Microsoft Excel table

Supplemental file 3. PRISMA flow diagram 
Supplemental file 4. Participant characteristics of controlled trials included $(\mathrm{k}=28)$

Data are presented as mean $\pm \mathrm{SD}$ or median (25th-75th percentiles) or mean [range].

12MWRT = 12-minutes walk-run test; 6MWT = 6-minutes walking test; BPD-DS = biliopancreatic diversion with duodenal switch; $\mathrm{BMI}=$ body mass index; $\mathrm{BS}=$ bariatric surgery; $\mathrm{CBT}=$ cognitive-behavioral therapy; $\mathrm{FFM}=$ fat free mass; GB = gastric banding; IPAQ-SF = International PA Questionnaire Short Form; HT = hypertension; $\mathrm{N}=$ baseline number of participants after randomization; $\mathrm{N}^{*}=$ final number of participants (for studies without sociodemographic data for the baseline number of participants after randomization); $\mathrm{NA}=$ not available; $\mathrm{PA}=$ physical activity; $\mathrm{QE}=$ quasi experimental study; RCT = randomized controlled study; RYGB = Roux-Y gastric bypass; $\mathrm{SG}=$ sleeve gastrectomy; T2D = type 2 diabetes; $y=$ years.

* The reported measurements were taken before BS, because there was no measurement at the beginning of the intervention after BS.

**To note, the ethnicity terms used in this table was those reported by included studies, and control group referred to comparison group without exercise intervention.

Supplemental file 5. Forest plots of feasibility and acceptability indicators of exercise and controlled trial methods in adults awaiting or having undergone bariatric surgery

Supplemental file 6. Forest plots of feasibility and acceptability indicators of exercise and controlled trial methods in adults awaiting or having undergone bariatric surgery according to studies quality

Supplemental file 7. Forest plots of feasibility and acceptability indicators of exercise and controlled trial methods in adults awaiting or having undergone bariatric surgery according to exercise training timing

Supplemental file 8. Forest plots of feasibility and acceptability indicators of exercise and controlled trial methods in adults awaiting or having undergone bariatric surgery according to intervention duration

Supplemental file 9. Summary of quality assessment of controlled trials included $(k=28)$

Criteria for controlled trials: (1) Randomized study; (2) Adequate randomization method; (3) Treatment allocation concealment; (4) Blinding treatment assignment; (5) Blinding outcome assessors; (6) Similar baseline characteristics; (7) Dropout rate $<20 \%$; (8) Differential dropout rate between groups $<15 \%$; (9) High attendance (i.e. participation to exercise training sessions $\geq 70 \%$ or proportion of completers $\geq 70 \%$ ); (10) Similar background treatments; (11) Valid and reliable outcome measures; (12) Sample size justification; (13) Pre-specified outcomes/subgroups; (14) All randomized participants analyzed (ITT analysis). Three criteria were defined as "fatal flaws" when not met: (1) Randomized study; (7) Dropout rate <20\%; (14) Intention-to-Treat analysis). Study quality was defined as good, fair and poor when 0,1 or $\geq 2$ fatal flaws were identified. 
Table 1.

\begin{tabular}{|c|c|}
\hline Name & Calculation \\
\hline \multicolumn{2}{|c|}{ Feasibility and acceptability of the exercise intervention } \\
\hline $\begin{array}{l}\text { Attendance rate (relates to session } \\
\text { frequency), \% (or otherwise) }\end{array}$ & Not calculated; reported by authors \\
\hline $\begin{array}{l}\text { Compliance rate (relates to session } \\
\text { duration and intensity), } \% \text { (or } \\
\text { otherwise) }\end{array}$ & Not calculated; reported by authors \\
\hline Dropout rate, $\%$ & $\begin{array}{l}=100 / \text { number of participants allocated to the intervention } \mathrm{x} \text { number of participants who discontinued the } \\
\text { intervention }\end{array}$ \\
\hline \multicolumn{2}{|c|}{ Feasibility and acceptability of controlled trial methods } \\
\hline Number of participants enrolled, $\mathrm{N}$ & $=$ number of participants assessed for eligibility (i.e., recruited) - number of participants excluded \\
\hline Refusal rate, $\%$ & $\begin{array}{l}=100 / \text { (number of participants enrolled }+ \text { number of participants who declined to participate) } x \text { number of } \\
\text { participants who declined to participate }\end{array}$ \\
\hline Recruitment rate, $\mathrm{n} /$ month & $=$ number of participants assessed for eligibility /recruitment duration (months) \\
\hline Enrollment speed, n/month & $=$ number of participants enrolled $/$ recruitment duration (months) \\
\hline Enrollment rate, \% & $=100 /$ number of participants assessed for eligibility $\mathrm{x}$ number of participants enrolled \\
\hline Retention rate, $\%$ & $\begin{array}{l}\text { = } 100 / \text { number of participants allocated to intervention } \mathrm{x} \text { (number of participants allocated to intervention - number } \\
\text { of participants lost to follow-up during the intervention phase) } \\
\text { For follow-up phase: }=100 / \text { number of participants at the beginning of follow-up } x \text { (number of participants at the } \\
\text { beginning of follow-up - number of participants lost to follow-up during the follow-up phase) }\end{array}$ \\
\hline Randomisation refusal rate, \% & $=100 /$ number of participants randomized $\mathrm{x}$ number of participants who refused randomization \\
\hline
\end{tabular}




\section{Author Year}

(Country)

Brief intervention name

$\begin{array}{lllll}\begin{array}{l}\text { Interventi } \\ \text { on }\end{array} & \begin{array}{l}\text { Intervention } \\ \text { length }\end{array} & \begin{array}{l}\text { Intervention } \\ \text { supervision }\end{array} & \begin{array}{l}\text { Intervent- } \\ \text { ion } \\ \text { ftarting }\end{array} & \begin{array}{l}\text { Intervention description } \\ \text { Exercise type and volume* }\end{array} \\ \text { time } & \text { Setting } & & \end{array}$

Attendance and compliance rate
Dropout rate r** $^{* *}$

Reasons
Adverse events during exercise

Studies with intervention delivered before BS

\begin{tabular}{|c|c|c|c|c|c|c|c|c|}
\hline $\begin{array}{l}\text { Funderburk } 2010 \\
\text { (USA) } \\
\text { Aquatic exercise } \\
\text { intervention }\end{array}$ & before BS & $\begin{array}{l}13 \text { wk. } \\
\text { Rehabilitation } \\
\text { center }\end{array}$ & $\begin{array}{l}\text { Supervised by } \\
\text { aquatic exercise } \\
\text { leaders }\end{array}$ & NA & $\begin{array}{l}\text { Aquatic strength and endurance exercises; Ai } \\
\text { Chi exercises for balance, core strengthening } \\
\text { and relaxation: } 2 \text { x } 60 \mathrm{~min} / \mathrm{wk} \text {. } \\
+ \text { Usual care }\end{array}$ & $\begin{array}{l}\text { Attendance: NA } \\
\text { Compliance: NA }\end{array}$ & NA & NA \\
\hline Usual care & before BS & Hospital & Physicians & NA & $\begin{array}{l}\text { Proceeding with gastric bypass surgery } \\
\text { preparation routine. }\end{array}$ & $\begin{array}{l}\text { Attendance: NA } \\
\text { Compliance: NA }\end{array}$ & NA & \\
\hline $\begin{array}{l}\text { Baillot } 2016 \\
\text { (Canada) } \\
\text { Endurance and } \\
\text { resistance training }\end{array}$ & $\begin{array}{l}3-6 \\
\text { months } \\
\text { before BS }\end{array}$ & $\begin{array}{l}12 \text { wk. } \\
\text { Gym in an } \\
\text { hospital } \\
\text { (possibility } \\
\text { sometimes at home) }\end{array}$ & $\begin{array}{l}\text { Supervised by } \\
\text { PA specialist }+ \\
\text { multidisciplinar } \\
\text { y team }\end{array}$ & $\begin{array}{l}\text { Group } \\
\text { (possibility } \\
\text { sometimes } \\
\text { individually) }\end{array}$ & $\begin{array}{l}\text { Treadmill, walking circuit, arm-ergocycle, } \\
\text { elliptical: } 3 \text { x } 60 \text { min/wk. }(55-85 \% \text { HRR }) \\
\text { Resistance: } 2-3 \text { series of } 12-15 \text { reps } \\
9 \text { exercises with small equipment ( } 20 \text { min) } \\
+ \text { Usual care }\end{array}$ & $\begin{array}{l}\text { Attendance: } \\
\mathbf{6 8 . 4 ( 5 2 . 8 - 9 2 . 1 )} \\
\% \text { of the total } \\
\text { exercise sessions } \\
\text { Compliance: NA }\end{array}$ & $\begin{array}{l}6.7 \% \\
- \text { had stomach pain } \\
\text { followed by } \\
\text { transportation } \\
\text { problem }\end{array}$ & $\begin{array}{l}\text { Occasional muscle or joint pain } \\
3 \text { hypoglycemia (one patient) } \\
\text { during exercise sessions }\end{array}$ \\
\hline Usual care & $\begin{array}{l}3-6 \\
\text { months } \\
\text { before BS }\end{array}$ & Hospital & $\begin{array}{l}\text { Multidisciplinar } \\
\text { y team }\end{array}$ & $\begin{array}{l}\text { Group }+ \\
\text { individual }\end{array}$ & $\begin{array}{l}15 \text { min PA and nutrition counselling meeting } \\
\text { every } 6 \text { wk. for the first } 6 \text { months, then every } 8 \\
\text { wk. until the surgery }+ \text { voluntary group meeting }\end{array}$ & $\begin{array}{l}\text { Attendance: NA } \\
\text { Compliance: NA }\end{array}$ & $0 \%$ & \\
\hline $\begin{array}{l}\text { Marcon } 2017 \\
\text { (Brazil) } \\
\text { Walk-simulating } \\
\text { endurance } \\
\text { training + lifestyle } \\
\text { modification }\end{array}$ & before BS & $\begin{array}{l}19 \text { wk. } \\
\text { Outpatient } \\
\text { clinic }\end{array}$ & $\begin{array}{l}\text { Supervised by } \\
\text { NA }\end{array}$ & NA & $\begin{array}{l}\text { Walking-simulating leg and bilateral arm } \\
\text { movement: } 2 \text { x } 25 \mathrm{~min} / \mathrm{wk} \text {. (2-4 Borg RPE) } \\
\text { CBT group therapy: } 60 \mathrm{~min} / \mathrm{wk} . \\
+ \text { Usual care }\end{array}$ & $\begin{array}{l}\text { Attendance: } \\
\mathbf{7 8 . 5} \pm \mathbf{1 3 . 3} \% \text { of } \\
\text { the total exercise } \\
\text { sessions } \\
\text { Compliance: NA }\end{array}$ & $\begin{array}{l}22.7 \% \\
-1 \text { surgery was } \\
\text { anticipated } \\
-4 \text { were unable to } \\
\text { attend intervention }\end{array}$ & NA \\
\hline $\begin{array}{l}\text { Walk-simulating } \\
\text { endurance } \\
\text { training }\end{array}$ & before BS & $\begin{array}{l}\text { Outpatient } \\
\text { clinic }\end{array}$ & $\begin{array}{l}\text { Supervised by } \\
\text { NA }\end{array}$ & NA & $\begin{array}{l}\text { Walking-simulating leg and bilateral arm } \\
\text { movement: } 2 \text { x } 25 \text { min/wk. (2-4 Borg RPE) } \\
+ \text { Usual care }\end{array}$ & $\begin{array}{l}\text { Attendance: } \\
\mathbf{8 0 . 9} \pm \mathbf{1 0 . 8} \% \text { of } \\
\text { the total exercise } \\
\text { sessions } \\
\text { Compliance: NA }\end{array}$ & $0 \%$ & \\
\hline
\end{tabular}




\begin{tabular}{|c|c|c|c|c|c|c|c|c|}
\hline Usual care & before BS & $\begin{array}{l}\text { Outpatient } \\
\text { clinic }\end{array}$ & $\begin{array}{l}\text { Multidisciplinar } \\
\text { y team }\end{array}$ & Individual & $\begin{array}{l}\text { Mandatory presence information meetings } \\
\text { about the importance of changing eating habits } \\
\text { and PA: } 5 \text { x } 90 \text { min. }\end{array}$ & $\begin{array}{l}\text { Attendance: } \\
\text { 100.0\% of the } \\
\text { information } \\
\text { meetings } \\
\text { Compliance: NA }\end{array}$ & $0 \%$ & \\
\hline $\begin{array}{l}\text { Picó-Sirvent } \\
2019 \\
\text { (Spain) } \\
\text { MICT-/HIIT- } \\
\text { endurance and } \\
\text { resistance training }\end{array}$ & before BS & $\begin{array}{l}26 \text { wk. } \\
\text { University } \\
\text { sport facilities }\end{array}$ & $\begin{array}{l}\text { Supervised by } \\
\text { sport science } \\
\text { graduates }\end{array}$ & NA & $\begin{array}{l}2-4 \text { x } 60 \text { to } 70 \mathrm{~min} / \mathrm{wk} \text {. } \\
\text { Treadmill, ergocycle: } 1-2 \mathrm{xICT}(60-85 \% \\
\text { HRpeak) }+2 \text { x HIIT }\left(60-95 \% \mathrm{VO}_{2} \text { peak) } / \text { wk. }\right. \\
\text { Resistance: } 2 \mathrm{x} / \mathrm{wk} .1-4 \text { series of } 10-20 \text { reps } \\
4-7 \text { exercises } \\
+ \text { Usual care }\end{array}$ & $\begin{array}{l}\text { Attendance: } \\
\mathbf{9 3 . 3} \pm \mathbf{6 . 5 \%} \text { of } \\
\text { the total exercise } \\
\text { sessions } \\
\text { Compliance: NA }\end{array}$ & $0 \%$ & None \\
\hline Usual care & before BS & Hospital & NA & NA & Usual presurgical care indication. & $\begin{array}{l}\text { Attendance: NA } \\
\text { Compliance: NA }\end{array}$ & $0 \%$ & \\
\hline $\begin{array}{l}\text { Marc-Hernández } \\
2019 \\
\text { (Spain) } \\
\text { (HIIT-)Endurance } \\
\text { and resistance } \\
\text { training }\end{array}$ & $\begin{array}{l}3-6 \\
\text { months } \\
\text { before BS }\end{array}$ & $\begin{array}{l}12 \mathrm{wk} . \\
\text { Research } \\
\text { center }\end{array}$ & $\begin{array}{l}\text { Supervised by } \\
\text { NA }\end{array}$ & NA & $\begin{array}{l}\text { Ergoycle, arm ergometer, elliptical, and } \\
\text { treadmill: } 2 \text { x } 35-50 \text { min continuous/wk. }(60- \\
80 \% \text { HRmax }+2 \text { x HIIT/wk. }(60-80 \% \\
\left.\mathrm{VO}_{2} \max \right) \\
\text { Resistance: } 1-4 \text { series of } 15-20 \text { reps } \\
4-7 \text { exercises with machines }(50-65 \% \text { RPM) } \\
+ \text { Usual care }\end{array}$ & $\begin{array}{l}\text { Attendance: NA } \\
\text { Compliance: NA }\end{array}$ & $\begin{array}{l}16.7 \% \\
-1 \text { left the program }\end{array}$ & NA \\
\hline Usual care & $\begin{array}{l}3-6 \\
\text { months } \\
\text { before BS }\end{array}$ & Hospital & $\begin{array}{l}\text { Multidisciplinar } \\
\text { y team }\end{array}$ & Individual & $\begin{array}{l}\text { Psychological and nutritional counseling. } \\
\text { Active lifestyle advice. }\end{array}$ & $\begin{array}{l}\text { Attendance: NA } \\
\text { Compliance: NA }\end{array}$ & Not clear & \\
\hline $\begin{array}{l}\text { Gilbertson } 2020 \\
\text { (USA) } \\
\text { Home walking }\end{array}$ & $\begin{array}{l}1 \text { month } \\
\text { before BS }\end{array}$ & $\begin{array}{l}4 \text { wk. } \\
\text { At home }\end{array}$ & $\begin{array}{l}\text { Semi- } \\
\text { supervised by } \\
\text { the research } \\
\text { team (Use of fitness } \\
\text { and activity tracker } \\
\text { Weekly texts, emails or } \\
\text { phone calls) }\end{array}$ & Individual & $\begin{array}{l}\text { Walking: } 5 \times 30 \mathrm{~min} / \mathrm{wk} .(65-85 \% \mathrm{HRmax}) \\
+ \text { Usual care }\end{array}$ & $\begin{array}{l}\text { Attendance: } \\
\mathbf{1 8 . 4} \pm \mathbf{3 . 0} \text { of } 20 \\
\text { scheduled } \\
\text { exercise sessions } \\
\text { Compliance: NA }\end{array}$ & $0 \%$ & None \\
\hline Usual care & $\begin{array}{l}1 \text { month } \\
\text { before BS }\end{array}$ & $\begin{array}{l}\text { Medical } \\
\text { center }\end{array}$ & $\begin{array}{l}\text { Multidisciplinar } \\
\text { y team }\end{array}$ & Individual & $\begin{array}{l}\text { Nutritional instructions and meal replacement } \\
\text { shakes. }\end{array}$ & $\begin{array}{l}\text { Attendance: NA } \\
\text { Compliance: NA }\end{array}$ & $0 \%$ & \\
\hline
\end{tabular}




\begin{tabular}{|c|c|c|c|c|c|c|c|c|}
\hline $\begin{array}{l}\text { Arman } 2021 \\
\text { (Turkey) } \\
\text { Core Stabilization } \\
\text { Exercise Program }\end{array}$ & $\begin{array}{l}3-6 \\
\text { months } \\
\text { before BS }\end{array}$ & $\begin{array}{l}8 \text { wk. } \\
\text { Facility based }\end{array}$ & $\begin{array}{l}\text { Supervised by } \\
\text { physiotherapists }\end{array}$ & Individual & $\begin{array}{l}2 \times 50-70 \mathrm{~min} / \mathrm{wk} \\
\text { Warm-up: treadmill } 10-15 \mathrm{~min} 50-60 \% \mathrm{HRmax} \\
\text { Core Stabilization Exercise Program } \\
\text { (strengthening, endurance and balance } \\
\text { exercises) } 1-2 \text { series of } 7-10 \text { reps } \\
7-12 \text { exercises ( } 50 \% \text { RPM) } \\
+ \text { Usual care }\end{array}$ & $\begin{array}{l}\text { Attendance: NA } \\
\text { Compliance: NA }\end{array}$ & $0 \%$ & NA \\
\hline Usual care & $\begin{array}{l}3-6 \\
\text { months } \\
\text { before BS }\end{array}$ & NA & $\begin{array}{l}\text { Supervised by } \\
\text { physiotherapists }\end{array}$ & Individual & $\begin{array}{l}\text { PA and sedentary advices and daily PA diary } \\
\text { with activities and number of steps. } \\
\text { (motivational phone call every } 2-3 \text { wk.) }\end{array}$ & $\begin{array}{l}\text { Attendance: NA } \\
\text { Compliance: NA }\end{array}$ & Not clear & \\
\hline \multicolumn{9}{|c|}{ Studies with intervention delivered after BS } \\
\hline $\begin{array}{l}\text { Castello } 2011 \\
\text { (Brazil) } \\
\text { Interval endurance } \\
\text { training }\end{array}$ & $\begin{array}{l}1 \text { month } \\
\text { after BS }\end{array}$ & $\begin{array}{l}12 \text { wk. } \\
\text { University } \\
\text { laboratory }\end{array}$ & $\begin{array}{l}\text { Supervised by } \\
\text { physiotherapist }\end{array}$ & Individual & Treadmill: 3 x 60min/wk. (50-70\% HRmax) & $\begin{array}{l}\text { Attendance: } \\
\begin{array}{l}\mathbf{1 0 0 . 0} \% \text { of } 32 \\
\text { exercise sessions }\end{array} \\
\text { Compliance: NA }\end{array}$ & $\begin{array}{l}31.3 \% \\
-3 \text { had trouble } \\
\text { balancing work and } \\
\text { training } \\
\text { - } 2 \text { disliked exercise } \\
\text { due to muscle or } \\
\text { joint pain }\end{array}$ & $\begin{array}{l}\text { Lower limb fatigue, mild } \\
\text { dyspnea and mild sweating } \\
\text { during exercise sessions }\end{array}$ \\
\hline$N A$ & NA & NA & NA & NA & NA & $\begin{array}{l}\text { Attendance: NA } \\
\text { Compliance: NA }\end{array}$ & $0 \%$ & \\
\hline $\begin{array}{l}\text { Shah } 2011 \\
\text { (USA) } \\
\text { High-volume } \\
\text { endurance } \\
\text { training + diet } \\
\text { intervention }\end{array}$ & $\begin{array}{l}\geq 3 \\
\text { months } \\
\text { after BS }\end{array}$ & $\begin{array}{l}12 \mathrm{wk} . \\
\text { Gym in a } \\
\text { medical center } \\
\text { (max. } 80 \% \text { at home) }\end{array}$ & $\begin{array}{l}\text { Semi- } \\
\text { supervised by } \\
\text { investigator }\end{array}$ & Individual & $\begin{array}{l}\text { Treadmill/walking and ergocycle/rowing: } 5 \\
\text { x/wk. }\left(60-70 \mathrm{VO}_{2} \mathrm{max}\right) \\
\text { Goal: expend } \geq 2000 \mathrm{kcal} / \mathrm{wk} . \\
\text { Exercise and diet-related behavioral therapy } \\
\text { every two wk.. }\end{array}$ & $\begin{array}{l}\text { Attendance: NA } \\
\text { Compliance: } \\
\begin{array}{l}\text { 30.0-53.0 \% } \\
\text { reached the goal }\end{array}\end{array}$ & $\begin{array}{l}23.8 \% \\
-5 \text { did not have } \\
\text { enough time to } \\
\text { exercise }\end{array}$ & $\begin{array}{l}\text { Occasional muscle or joint } \\
\text { soreness }\end{array}$ \\
\hline Diet intervention & $\begin{array}{l}\geq 3 \\
\text { months } \\
\text { after BS }\end{array}$ & $\begin{array}{l}\text { Research } \\
\text { center or by } \\
\text { telephone }\end{array}$ & Investigator & Individual & $\begin{array}{l}\text { Behavioral diet-related intervention and } \\
\text { feedback on diet every two wk. }\end{array}$ & $\begin{array}{l}\text { Attendance: NA } \\
\text { Compliance: NA }\end{array}$ & $\begin{array}{l}33.3 \% \\
-3 \text { preferred to be } \\
\text { in the exercise } \\
\text { group } \\
-1 \text { had no time }\end{array}$ & \\
\hline
\end{tabular}




\begin{tabular}{|c|c|c|c|c|c|c|c|c|}
\hline $\begin{array}{l}\text { Stegen } 2011 \\
\text { (Belgium) } \\
\text { Progressive } \\
\text { endurance and } \\
\text { resistance training }\end{array}$ & $\begin{array}{l}1 \text { month } \\
\text { after BS }\end{array}$ & $\begin{array}{l}12 \text { wk. } \\
\text { University } \\
\text { rehabilitation } \\
\text { facilities }\end{array}$ & $\begin{array}{l}\text { Supervised by } \\
\text { movement and } \\
\text { rehabilitation } \\
\text { sciences master } \\
\text { students }\end{array}$ & Individual & $\begin{array}{l}\text { Cycling, walking and stepping: } 3 \text { x } 75 \text { min/wk. } \\
\text { (60-75\% HRR) } \\
\text { Resistance: } 1-3 \text { series of } 10-15 \text { reps of knee/ } \\
\text { elbow flexion/extension exercises using stack- } \\
\text { weight equipment ( } 60-75 \% \text { RPM, } 25 \text { min) }\end{array}$ & $\begin{array}{l}\text { Attendance: NA } \\
\text { Compliance: NA }\end{array}$ & Not clear & NA \\
\hline$N A$ & $\begin{array}{l}1 \text { month } \\
\text { after BS }\end{array}$ & NA & NA & NA & NA & $\begin{array}{l}\text { Attendance: NA } \\
\text { Compliance: NA }\end{array}$ & Not clear & \\
\hline $\begin{array}{l}\text { Coen } 2015 \\
\text { (USA) } \\
\text { Endurance } \\
\text { training }\end{array}$ & $\begin{array}{l}1-3 \\
\text { months } \\
\text { after BS }\end{array}$ & $\begin{array}{l}26 \text { wk. } \\
\text { Research } \\
\text { center } \\
\text { or at home } \\
\text { or outdoors }\end{array}$ & $\begin{array}{l}\text { Semi- } \\
\text { supervised by } \\
\text { trained exercise } \\
\text { physiologists } \\
\text { (at least I session/wk.) }\end{array}$ & Individual & $\begin{array}{l}\text { Ergocycle, treadmill, cycling and walking } \\
\text { outdoors: } 3-5 \times 10-30 \mathrm{~min} / \mathrm{wk} .(60-70 \% \\
\text { HRmax); Goal: expand } \geq 120 \mathrm{~min} / \mathrm{wk} . \\
+ \text { Health education }\end{array}$ & $\begin{array}{l}\text { Attendance: NA } \\
\text { Compliance: } \\
\text { 66.7\% reached } \\
\text { the goal }\end{array}$ & $\begin{array}{l}9.1 \% \\
-5 \text { had time- } \\
\text { commitment issues } \\
-1 \text { was lost to } \\
\text { follow-up }\end{array}$ & None \\
\hline Health education & $\begin{array}{l}1-3 \\
\text { months } \\
\text { after BS }\end{array}$ & NA & NA & Group & $\begin{array}{l}\text { Monthly health education sessions (medication, } \\
\text { nutrition, PA). PA habit reports. }\end{array}$ & $\begin{array}{l}\text { Attendance: NA } \\
\text { Compliance: } \\
\mathbf{9 0 . 3 \% \text { reported } >} \\
30 \mathrm{~min} \mathrm{PA} / \mathrm{wk} \text {. }\end{array}$ & $\begin{array}{l}4.8 \% \\
-1 \text { moved away } \\
-1 \text { was lost to } \\
\text { follow-up } \\
-1 \text { pregnancy }\end{array}$ & \\
\hline $\begin{array}{l}\text { Huck } 2015 \\
\text { (USA) } \\
\begin{array}{l}\text { Multifaceted } \\
\text { resistance training }\end{array}\end{array}$ & $\begin{array}{l}1-12 \\
\text { months } \\
\text { after BS }\end{array}$ & $\begin{array}{l}12 \text { wk. } \\
\text { Community- } \\
\text { based training } \\
\text { facility }\end{array}$ & $\begin{array}{l}\text { Supervised by } \\
\text { certified } \\
\text { strength and } \\
\text { conditioning } \\
\text { specialist }\end{array}$ & Group & $\begin{array}{l}\text { Resistance: } 1-3 \text { series of } 8-12 \text { reps } \\
8-10 \text { exercises with stack-weight equipment, } \\
\text { free weights, resistive bands and body weight. } \\
2-3 \times 60 \mathrm{~min} / \mathrm{wk} .(60-75 \% \mathrm{RPM}) \\
+ \text { Usual care }\end{array}$ & $\begin{array}{l}\text { Attendance: } \\
\text { 84.0\% of training } \\
\text { sessions } \\
\text { Compliance: NA }\end{array}$ & Not clear & None \\
\hline Usual care & $\begin{array}{l}1-12 \\
\text { months } \\
\text { after BS }\end{array}$ & NA & Clinicians & NA & $\begin{array}{l}\text { Encouragement to increase PA and consume } \\
\text { protein shakes. }\end{array}$ & $\begin{array}{l}\text { Attendance: NA } \\
\text { Compliance: NA }\end{array}$ & Not clear & \\
\hline $\begin{array}{l}\text { Marchesi } 2015 \\
\text { (Italy) } \\
\text { Road running } \\
\text { training }\end{array}$ & $\begin{array}{l}12-36 \\
\text { months } \\
\text { after BS }\end{array}$ & $\begin{array}{l}44 \text { wk. } \\
\text { NA }\end{array}$ & $\begin{array}{l}\text { Supervised by } \\
\text { sport physician } \\
\text { (1 self-managed } \\
\text { session/wk in the last } 20 \\
w k .)\end{array}$ & NA & $\begin{array}{l}\text { Indoor or outdoor road running: } 3-4 \text { x } 60 \\
\text { min/wk.; goal: participation in a } 10.5 \mathrm{~km} \\
\text { competitive run (55-90\% HRmax) } \\
\text { Physiological assistance and specialized } \\
\text { nutritional counseling. }\end{array}$ & $\begin{array}{l}\text { Attendance: NA } \\
\text { Compliance: NA }\end{array}$ & $\begin{array}{l}30.0 \% \\
-3 \text { lacked } \\
\text { motivation }\end{array}$ & $\begin{array}{l}\text { Symptomatic cholelithiasis } \\
\text { (resolved after } 3 \text {-wk break) }\end{array}$ \\
\hline$N A$ & $\begin{array}{l}12-13 \\
\text { months }\end{array}$ & NA & NA & NA & - & Attendance: NA & $0 \%$ & \\
\hline
\end{tabular}




\begin{tabular}{|c|c|c|c|c|c|c|c|c|}
\hline & after BS & & & & & Compliance: NA & & \\
\hline $\begin{array}{l}\text { Muschitz } 2016 \\
\text { (Austria) } \\
\\
\text { Endurance and } \\
\text { resistance training } \\
+ \text { specific } \\
\text { supplementation }\end{array}$ & $\begin{array}{l}2 \text { wk. after } \\
\text { BS }\end{array}$ & $\begin{array}{l}104 \text { wk. } \\
\text { At home }\end{array}$ & $\begin{array}{l}\text { Semi- } \\
\text { supervised } \\
\text { Monitored by } \\
\text { physical } \\
\text { medicine } \\
\text { experts }\end{array}$ & Individual & $\begin{array}{l}\text { Nordic walking: at least } 3 \times 45 \mathrm{~min} / \mathrm{wk} . \\
\text { Resistance perseverance and equipment } \\
\text { training: at least } 2 \times 30 \mathrm{~min} / \mathrm{wk} . \\
\text { Specific vitamin, mineral and protein } \\
\text { supplementation before BS and after BS. } \\
+ \text { Usual care }\end{array}$ & $\begin{array}{l}\text { Attendance: } \\
\mathbf{8 8 . 2} \% \text { completed } \\
\geq 80 \% \text { exercise } \\
\text { requirements } \\
\text { Compliance: NA }\end{array}$ & Not clear & NA \\
\hline Usual care & $\begin{array}{l}2 \text { wk. after } \\
\text { BS }\end{array}$ & NA & $\begin{array}{l}\text { Telephone } \\
\text { interviews }\end{array}$ & NA & $\begin{array}{l}\text { Advice on PA and balanced nutrition. Basic } \\
\text { supplementation. }\end{array}$ & $\begin{array}{l}\text { Attendance: NA } \\
\text { Compliance: NA }\end{array}$ & $\begin{array}{l}14.5 \% \\
-12 \text { were unwilling } \\
\text { to stay in the study } \\
-4 \text { got new jobs } \\
\text { outside the area }\end{array}$ & \\
\hline $\begin{array}{l}\text { Rojhani-Shirazi } \\
2016 \\
\text { (Iran) }\end{array}$ & $\begin{array}{l}5 \text { days } \\
\text { after BS }\end{array}$ & $\begin{array}{l}4 \text { wk. } \\
\text { NA }\end{array}$ & NA & NA & $\begin{array}{l}\text { Balance training with periodic exercises (e.g., } \\
\text { standing one leg or walking on toes): } 4 \text { x } 45 \\
\mathrm{~min} / \mathrm{wk} \text {. }\end{array}$ & $\begin{array}{l}\text { Attendance: NA } \\
\text { Compliance: NA }\end{array}$ & NA & NA \\
\hline Balance training & & & & & & & & \\
\hline$N A$ & after BS & NA & NA & NA & NA & $\begin{array}{l}\text { Attendance: NA } \\
\text { Compliance: NA }\end{array}$ & NA & \\
\hline $\begin{array}{l}\text { Campanha- } \\
\text { Versiani } 2017 \\
\text { (Brazil) } \\
\text { Endurance and } \\
\text { resistance training }\end{array}$ & $\begin{array}{l}3 \text { months } \\
\text { after BS }\end{array}$ & $\begin{array}{l}36 \text { wk. } \\
\text { NA }\end{array}$ & $\begin{array}{l}\text { Supervised by } \\
\text { NA }\end{array}$ & NA & $\begin{array}{l}\text { Treadmill: } 2 \times 25 \mathrm{~min} / \mathrm{wk} .(70-80 \% \mathrm{HRmax}) \\
\text { Resistance: } 1-3 \text { series of } 10-12 \text { reps at } 10 \mathrm{RM} \\
\text { maximum load } \\
8 \text { exercises }(2 \times 60 \mathrm{~min} / \mathrm{wk} .) \\
+ \text { Usual care }\end{array}$ & $\begin{array}{l}\text { Attendance: } \\
\mathbf{6 0 . 0} \% \text { attended } \geq \\
95 \% \text { scheduled } \\
\text { exercise sessions } \\
\text { Compliance: NA }\end{array}$ & Not clear & NA \\
\hline Usual care & $\begin{array}{l}3 \text { months } \\
\text { after BS }\end{array}$ & NA & NA & NA & $\begin{array}{l}\text { Dietary counseling. Multivitamin and mineral } \\
\text { supplementation. }\end{array}$ & $\begin{array}{l}\text { Attendance: NA } \\
\text { Compliance: NA }\end{array}$ & Not clear & \\
\hline
\end{tabular}




\begin{tabular}{|c|c|c|c|c|c|c|c|c|}
\hline $\begin{array}{l}\text { Coleman } 2017 \\
\text { (USA) } \\
\text { Functional } \\
\text { resistance training }\end{array}$ & $\begin{array}{l}6-24 \\
\text { months } \\
\text { after BS }\end{array}$ & $\begin{array}{l}52 \text { wk. } \\
\text { NA }\end{array}$ & $\begin{array}{l}\text { Semi- } \\
\text { supervised by } \\
\text { NA } \\
(60 \% \text { self-directed } \\
\text { exercise) }\end{array}$ & $\begin{array}{l}\text { Group }+ \\
\text { Individual }\end{array}$ & $\begin{array}{l}\text { Functional resistance, aerobic and flexibility } \\
\text { training with body weight: } 2 \times 60 \mathrm{~min} / \mathrm{wk} \text {. } \\
\text { Self-directed exercise } 3 \times / \mathrm{wk} . \\
\text { Goal: MVPA } \geq 150 \mathrm{~min} / \mathrm{wk} \text {. } \\
\text { Weekly phone counseling. Step counting. } \\
+ \text { maintenance phase with booster exercise } \\
\text { sessions and social support }\end{array}$ & $\begin{array}{l}\text { Attendance: NA } \\
\mathbf{3 2 . 0 - 5 6 . 0 \%} \text { of } \\
\text { the supervised } \\
\text { exercise sessions } \\
\text { Compliance: NA }\end{array}$ & $\begin{array}{l}7.7 \% \\
-2 \text { lacked of time }\end{array}$ & $\begin{array}{l}\text { - } 44 \% \text { with initial functionality } \\
\text { developed condition during } \\
\text { intervention }\end{array}$ \\
\hline Usual care & $\begin{array}{l}6-24 \\
\text { months } \\
\text { after BS }\end{array}$ & Hospital & $\begin{array}{l}\text { Nurse care } \\
\text { managers }\end{array}$ & Individual & $\begin{array}{l}\text { Dietary and PA counseling } 2 \text { wk., } 2 \text { months and } \\
6 \text { months after surgery. }\end{array}$ & $\begin{array}{l}\text { Attendance: NA } \\
\text { Compliance: NA }\end{array}$ & $0 \%$ & \\
\hline $\begin{array}{l}\text { Herring } 2017 \\
\text { (UK) } \\
\text { Endurance and } \\
\text { resistance training }\end{array}$ & $\begin{array}{l}12-24 \\
\text { months } \\
\text { after BS }\end{array}$ & $\begin{array}{l}12 \mathrm{wk} . \\
\text { Outpatient } \\
\text { clinic }\end{array}$ & $\begin{array}{l}\text { Supervised by } \\
\text { qualified gym } \\
\text { instructor }\end{array}$ & Individual & $\begin{array}{l}3 \text { x } 60 \mathrm{~min} / \mathrm{wk} . \\
\text { Endurance: } 64-77 \% \text { HRmax, 12-14 Borg RPE } \\
\text { Resistance: } 3 \text { series of } 12 \text { reps } \\
2 \text { exercises ( } 60 \% \text { RPM, } 25 \mathrm{~min}) \\
\\
\text { Diet information }\end{array}$ & $\begin{array}{l}\text { Attendance: } \\
\mathbf{9 5 . 0 \%} \text { of } 36 \\
\text { scheduled } \\
\text { exercise sessions } \\
\text { Compliance: NA }\end{array}$ & $\begin{array}{l}8.3 \% \\
-1 \text { had gastric band } \\
\text { deflated }\end{array}$ & None \\
\hline Usual care & $\begin{array}{l}12-24 \\
\text { months } \\
\text { after BS }\end{array}$ & NA & NA & Individual & $\begin{array}{l}\text { Advice session of } 30-60 \text { min on PA upon study } \\
\text { discharge and diet information. }\end{array}$ & $\begin{array}{l}\text { Attendance: NA } \\
\text { Compliance: NA }\end{array}$ & $\begin{array}{l}16.7 \% \\
-2 \text { preferred to be } \\
\text { in the exercise } \\
\text { group }\end{array}$ & \\
\hline $\begin{array}{l}\text { Onofre } 2017 \\
\text { (Brazil) } \\
\text { Endurance and } \\
\text { resistance training }\end{array}$ & $\begin{array}{l}3 \text { months } \\
\text { after BS }\end{array}$ & $\begin{array}{l}12 \text { wk. } \\
\text { University } \\
\text { hospital }\end{array}$ & $\begin{array}{l}\text { Supervised by } \\
\text { physiotherapist }\end{array}$ & NA & $\begin{array}{l}\text { Treadmill: } 3 \text { x } 60 \mathrm{~min} / \text { wk. }(40-60 \% \text { HRR and } \\
\text { 85-90\% HRR) } \\
\text { Resistance: upper and lower limp exercises (60- } \\
80 \% \text { RPM, } 25 \text { min) }\end{array}$ & $\begin{array}{l}\text { Attendance: NA } \\
\text { Compliance: NA }\end{array}$ & $0 \%$ & None \\
\hline Usual care & $\begin{array}{l}3 \text { months } \\
\text { after BS }\end{array}$ & NA & NA & NA & General guidelines for the importance of PA & $\begin{array}{l}\text { Attendance: NA } \\
\text { Compliance: NA }\end{array}$ & $0 \%$ & \\
\hline $\begin{array}{l}\text { Daniels } 2017 \\
\text { (USA) } \\
\text { Progressive } \\
\text { resistance training }\end{array}$ & $\begin{array}{l}2 \text { months } \\
\text { after BS }\end{array}$ & $\begin{array}{l}12 \text { wk. } \\
\text { NA }\end{array}$ & NA & NA & $\begin{array}{l}\text { Resistance: } 1-4 \text { series of } 8-15 \text { reps on } 8-10 \\
\text { exercises, } 3 \text { x } 60-80 \mathrm{~min} / \mathrm{wk} .(50->80 \% \mathrm{RPM})\end{array}$ & $\begin{array}{l}\text { Attendance: NA } \\
\text { Compliance: NA }\end{array}$ & $0 \%$ & NA \\
\hline Control & $\begin{array}{l}2 \text { months } \\
\text { after BS }\end{array}$ & NA & NA & NA & Instruction to continue normal daily activities. & $\begin{array}{l}\text { Attendance: NA } \\
\text { Compliance: NA }\end{array}$ & $0 \%$ & \\
\hline
\end{tabular}




\begin{tabular}{|c|c|c|c|c|c|c|c|c|}
\hline $\begin{array}{l}\text { Hassannejad } \\
2017 \\
\text { (Iran) } \\
\text { Endurance training } \\
\text { + resistance } \\
\text { training }\end{array}$ & $\begin{array}{l}\text { Just after } \\
\text { BS }\end{array}$ & $\begin{array}{l}12 \mathrm{wk} . \\
\text { At home }\end{array}$ & $\begin{array}{l}\text { No supervision } \\
\text { Daily activity } \\
\text { log books }\end{array}$ & Individual & $\begin{array}{l}\text { Resistance: Shoulder and hip exercises with } \\
\text { elastic bands, } 3 \text { x 20-30 min/wk. } \\
\text { Walking: } 3-5 \text { x 20-30 min/wk. (12-14 Borg } \\
\text { RPE) }\end{array}$ & $\begin{array}{l}\text { Attendance: NA } \\
\text { Compliance: NA }\end{array}$ & Not clear & NA \\
\hline Endurance training & $\begin{array}{l}\text { Just after } \\
\text { BS }\end{array}$ & At home & $\begin{array}{l}\text { No supervision } \\
\text { Daily activity } \\
\text { log books }\end{array}$ & Individual & $\begin{array}{l}\text { Walking: } 3-5 \text { x 20-30 min/wk. (12-14 Borg } \\
\text { RPE) }\end{array}$ & $\begin{array}{l}\text { Attendance: NA } \\
\text { Compliance: NA }\end{array}$ & Not clear & NA \\
\hline Diet education & $\begin{array}{l}\text { Just after } \\
\text { BS }\end{array}$ & NA & Nutritionist & Individual & $\begin{array}{l}\text { Education about standard high-protein diet after } \\
\text { BS. }\end{array}$ & $\begin{array}{l}\text { Attendance: NA } \\
\text { Compliance: NA }\end{array}$ & Not clear & \\
\hline $\begin{array}{l}\text { Mundbjerg } 2018 \\
\text { (Denmark) } \\
\text { Endurance and } \\
\text { resistance physical } \\
\text { training }\end{array}$ & $\begin{array}{l}6 \text { months } \\
\text { after BS }\end{array}$ & $\begin{array}{l}26 \mathrm{wk} . \\
\text { Fitness center }\end{array}$ & $\begin{array}{l}\text { Supervised by } \\
\text { physiologists } \\
\text { (additional individual } \\
\text { sessions) }\end{array}$ & NA & $\begin{array}{l}2 \times 40 \mathrm{~min} / \mathrm{wk} \\
\text { Ergoycle, stair climbing, treadmill, rowing } \\
\left(2 \times 30 \mathrm{~min}, 50-70 \% \mathrm{VO}_{2} \mathrm{max} / 15-17 \text { Borg }\right. \\
\mathrm{RPE}) \\
\text { Resistance: upper extremities ( } 2 \times 10 \mathrm{~min}) \\
\text { goal: } \mathrm{PA} \geq 210 \mathrm{~min} / \mathrm{wk} . \\
+ \text { Usual care }\end{array}$ & $\begin{array}{l}\text { Attendance: } \\
\mathbf{5 9 . 4} \% \text { attended } \geq \\
50 \% \text { scheduled } \\
\text { exercise sessions } \\
\text { Compliance: NA }\end{array}$ & Not clear & NA \\
\hline Usual care & $\begin{array}{l}6 \text { months } \\
\text { after BS }\end{array}$ & NA & NA & NA & Standard dietary recommendations. & $\begin{array}{l}\text { Attendance: NA } \\
\text { Compliance: NA }\end{array}$ & Not clear & \\
\hline $\begin{array}{l}\text { Oppert } 2018 \\
\text { (France) } \\
\text { Resistance } \\
\text { training + protein }\end{array}$ & $\begin{array}{l}6 \text { wk. after } \\
\text { BS }\end{array}$ & $\begin{array}{l}18 \text { wk. } \\
\text { University } \\
\text { hospital }\end{array}$ & $\begin{array}{l}\text { Supervised by } \\
\text { qualified } \\
\text { trainers }\end{array}$ & Group & $\begin{array}{l}\text { Resistance: } 4 \text { series of } 8-12 \text { reps } \\
6 \text { exercises, } 3 \times 60 \text { min/wk. }(50-75 \% \text { RPM }) \\
\text { Whey protein supplementation, } 2 \times \text { per day } \\
+ \text { Usual care }\end{array}$ & $\begin{array}{l}\text { Attendance: } \\
\mathbf{4 7 . 8} \% \text { completed } \\
\geq 2 \text { exercise } \\
\text { sessions/wk. and } \\
\text { nutritional } \\
\text { requirements } \\
\text { Compliance: NA }\end{array}$ & $0 \%$ & None \\
\hline $\begin{array}{l}\text { Usual care + } \\
\text { protein }\end{array}$ & $\begin{array}{l}1 \text { wk. after } \\
\text { BS }\end{array}$ & NA & No supervision & Individual & $\begin{array}{l}\text { Whey protein supplementation, } 2 \mathrm{x} \text { per day. } \\
+ \text { Usual care }\end{array}$ & $\begin{array}{l}\text { Attendance: } \\
\mathbf{4 5 . 2} \% \text { completed } \\
\text { all visits and } \\
\text { nutritional } \\
\text { requirements } \\
\text { Compliance: NA }\end{array}$ & $0 \%$ & \\
\hline
\end{tabular}




\begin{tabular}{|c|c|c|c|c|c|c|c|c|}
\hline Usual care & Before BS & NA & NA & Individual & $\begin{array}{l}\text { Nutrition and PA advice. Prescription of iron, } \\
\text { multivitamin and mineral supplementation from } \\
15 \text { days before BS. }\end{array}$ & $\begin{array}{l}\text { Attendance: } \\
\text { 100.0\% of } \\
\text { scheduled visits } \\
\text { Compliance: NA }\end{array}$ & $0 \%$ & \\
\hline $\begin{array}{l}\text { Murai } 2019 \\
\text { (Brazil) } \\
\text { Endurance and } \\
\text { resistance training }\end{array}$ & $\begin{array}{l}3 \text { months } \\
\text { after BS }\end{array}$ & $\begin{array}{l}26 \text { wk. } \\
\text { Hospital }\end{array}$ & $\begin{array}{l}\text { Supervised by } \\
\text { NA }\end{array}$ & Individual & $\begin{array}{l}\text { Treadmill: } 3 \text { x } 60-90 \mathrm{~min} / \mathrm{wk} .(50 \% \text { VAT-RCP) } \\
\text { Resistance: } 3 \text { series of } 8-12 \text { reps on } 7 \text { exercises } \\
+ \text { Health education }\end{array}$ & $\begin{array}{l}\text { Attendance: NA } \\
\mathbf{8 1 . 5} \pm \mathbf{1 3 . 1} \% \text { of } \\
\text { total exercise } \\
\text { sessions } \\
\text { Compliance: NA }\end{array}$ & $0 \%$ & None \\
\hline Health education & $\begin{array}{l}3 \text { months } \\
\text { after BS }\end{array}$ & NA & NA & NA & $\begin{array}{l}\text { Advice on calcium, vitamin D3 and protein } \\
\text { intake. Encouraged to improve PA levels } \\
\text { during follow-up }\end{array}$ & $\begin{array}{l}\text { Attendance: NA } \\
\text { Compliance: NA }\end{array}$ & $0 \%$ & \\
\hline $\begin{array}{l}\text { Diniz-Souza } \\
2020 \\
\text { (Portugal) } \\
\\
\text { Multicomponent } \\
\text { resistance training } \\
+ \text { Usual care }\end{array}$ & $\begin{array}{l}1 \text { month } \\
\text { after BS }\end{array}$ & $\begin{array}{l}47 \text { wk. } \\
\text { Facility based }\end{array}$ & $\begin{array}{l}\text { Supervised by } \\
\text { exercise trainer }\end{array}$ & Group & $\begin{array}{l}\text { High-impact training: High ground-reaction } \\
\text { force exercises (183-209 gravitational loading } \\
\text { peaks }>4.9 \mathrm{~g}, 20 \mathrm{~min}) \\
\text { Resistance training: } 2-3 \text { series of } 4-12 \text { reps } \\
7-8 \text { exercises }(65-85 \% \text { RPM, } 35 \mathrm{~min}) \\
3 \times 75 \mathrm{~min} / \mathrm{wk} \text {. } \\
+ \text { Usual care }\end{array}$ & $\begin{array}{l}\text { Attendance: } \\
\mathbf{3 9 . 0} \% \text { attended } \geq \\
50 \% \text { scheduled } \\
\text { exercise sessions } \\
\text { Compliance: NA }\end{array}$ & Not clear & $\begin{array}{l}\text { - } 10 \text { required ad hoc exercise } \\
\text { program adjustment ( } 4 \text { knee } \\
\text { pain, } 2 \text { lower back pain, } 1 \\
\text { diffuse lower limbs pain) and } \\
\text { temporarily interrupted the } \\
\text { intervention ( } 1 \text { rolled ankle and } \\
1 \text { hand bruise outside the study, } \\
1 \text { back bruise after fall in } \\
\text { exercise session) }\end{array}$ \\
\hline Usual care & $\begin{array}{l}1 \text { month } \\
\text { after BS }\end{array}$ & NA & NA & Individual & $\begin{array}{l}\text { Prescription of proton-pump inhibitors and } \\
\text { structured PA. Supplementation advice. }\end{array}$ & $\begin{array}{l}\text { Attendance: NA } \\
\text { Compliance: NA }\end{array}$ & Not clear & \\
\hline $\begin{array}{l}\text { Tardif } 2020 \\
\text { (Canada) } \\
\text { Moderate } \\
\text { endurance and } \\
\text { resistance training }\end{array}$ & $\begin{array}{l}3 \text { months } \\
\text { after BS }\end{array}$ & $\begin{array}{l}12 \text { wk. } \\
\text { Medical } \\
\text { center }\end{array}$ & $\begin{array}{l}\text { Supervised by } \\
\text { NA }\end{array}$ & NA & $\begin{array}{l}\text { Moderate endurance training }(50-75 \% \mathrm{HRR}) \\
\text { and resistance training }(25 \mathrm{~min}): 3 \times 60 \mathrm{~min} / \mathrm{wk} .\end{array}$ & $\begin{array}{l}\text { Attendance: } \\
\mathbf{2 8 . 0} \% \text { attended } \\
85 \% \text { scheduled } \\
\text { exercise sessions } \\
\text { Compliance: } \\
100 \%\end{array}$ & $0 \%$ & $11 \%$ hypotension \\
\hline NA & $\begin{array}{l}3 \text { months } \\
\text { after BS }\end{array}$ & NA & NA & NA & NA & $\begin{array}{l}\text { Attendance: NA } \\
\text { Compliance: } \\
100 \%\end{array}$ & $0 \%$ & \\
\hline
\end{tabular}




\begin{tabular}{|c|c|c|c|c|c|c|c|c|}
\hline $\begin{array}{l}\text { Marc-Hernández } \\
2020 \\
\text { (Spain) } \\
\text { ACT- and HIIT- } \\
\text { endurance and } \\
\text { resistance training }\end{array}$ & $\begin{array}{l}37 \text { months } \\
\text { after BS }\end{array}$ & $\begin{array}{l}20 \text { wk. } \\
\text { Sport } \\
\text { Research } \\
\text { Center }\end{array}$ & $\begin{array}{l}\text { Supervised by } \\
\text { sports science } \\
\text { graduates }\end{array}$ & NA & $\begin{array}{l}\text { Ergocycle, elliptical, treadmill: ACT ( } 60-85 \% \\
\left.\text { HRmax, and HIIT ( } 60-95 \% \mathrm{VO}_{2} \mathrm{max}\right), 2-4 \mathrm{x} \\
50 \mathrm{~min} / \mathrm{wk} \text {. } \\
\text { Resistance: } 1-4 \text { series of } 4-7 \text { reps } \\
4-7 \text { exercises ( } 50-75 \% \text { RPM, } 8-28 \mathrm{~min})\end{array}$ & $\begin{array}{l}\text { Attendance: } \\
\text { 90.9\% attended } \geq \\
85 \% \text { scheduled } \\
\text { exercise sessions } \\
\text { Compliance: NA }\end{array}$ & $0 \%$ & NA \\
\hline Usual care & $\begin{array}{l}37 \text { months } \\
\text { after BS }\end{array}$ & Hospital & NA & NA & NA & $\begin{array}{l}\text { Attendance: NA } \\
\text { Compliance: NA }\end{array}$ & $\begin{array}{l}20.0 \% \\
-2 \text { refused to } \\
\text { continue }\end{array}$ & \\
\hline $\begin{array}{l}\text { Lamarca } 2021 \\
\text { (Brazil) } \\
\text { Resistance } \\
\text { training + protein }\end{array}$ & $\begin{array}{l}\text { 2-7 years } \\
\text { after BS }\end{array}$ & $\begin{array}{l}12 \text { wk. } \\
\text { Facility based }\end{array}$ & $\begin{array}{l}\text { Supervised by } \\
\text { qualified } \\
\text { professionals }\end{array}$ & NA & $\begin{array}{l}\text { Resistance: } 3 \text { series of } 8-12 \text { reps on } 8 \text { exercises, } \\
3 \times 80 \text { min/wk. (6-9 on OMINI-RES) } \\
\text { Whey protein supplementation and general } \\
\text { training on healthy eating. }\end{array}$ & $\begin{array}{l}\text { Attendance: } \\
\mathbf{8 0 . 0} \pm 7.7 \% \text { of } \\
\text { scheduled } \\
\text { exercise sessions } \\
\text { Compliance: NA }\end{array}$ & Not clear & None \\
\hline $\begin{array}{l}\text { Resistance } \\
\text { training }+ \text { placebo }\end{array}$ & $\begin{array}{l}\text { 2-7 years } \\
\text { after BS }\end{array}$ & Facility based & $\begin{array}{l}\text { Supervised by } \\
\text { qualified } \\
\text { professionals }\end{array}$ & NA & $\begin{array}{l}\text { Resistance: } 3 \text { series of } 8-12 \text { reps on } 8 \text { exercises, } \\
3 \times 80 \mathrm{~min} / \mathrm{wk} \text {. (6-9 on OMINI-RES) } \\
\text { Placebo Maltodextrin and general training on } \\
\text { healthy eating }\end{array}$ & $\begin{array}{l}\text { Attendance: } \\
\mathbf{8 4 . 8} \pm \mathbf{5 . 4} \% \text { of } \\
\text { scheduled } \\
\text { exercise sessions } \\
\text { Compliance: NA }\end{array}$ & Not clear & NA \\
\hline Protein & $\begin{array}{l}2-7 \text { years } \\
\text { after BS }\end{array}$ & At home & No supervision & Individual & $\begin{array}{l}\text { Whey protein supplementation and general } \\
\text { training on healthy eating. }\end{array}$ & $\begin{array}{l}\text { Attendance: NA } \\
\text { Compliance: NA }\end{array}$ & Not clear & \\
\hline Placebo & $\begin{array}{l}2-7 \text { years } \\
\text { after BS }\end{array}$ & At home & No supervision & Individual & $\begin{array}{l}\text { Placebo Maltodextrin and general training on } \\
\text { healthy eating }\end{array}$ & $\begin{array}{l}\text { Attendance: NA } \\
\text { Compliance: NA }\end{array}$ & Not clear & \\
\hline
\end{tabular}


Table 3.

\section{Feasibility and acceptability data}

\begin{tabular}{|c|c|c|c|c|c|}
\hline \multirow[b]{2}{*}{ Total attendance rate - exercise intervention } & \multirow{2}{*}{$\begin{array}{l}\text { Arm } \\
\text { numbers } \\
\mathbf{1 0}\end{array}$} & \multirow{2}{*}{$\begin{array}{l}\% \\
84.3\end{array}$} & \multicolumn{2}{|c|}{$95 \% \mathrm{CI}$} & \multirow{2}{*}{$\begin{array}{l}\mathrm{I}^{2} \\
\mathbf{0 . 0}\end{array}$} \\
\hline & & & 77.0 & 90.7 & \\
\hline \multirow[t]{2}{*}{ Study quality: } & 6 & 83.9 & 70.6 & 94.1 & 9.4 \\
\hline & 4 & 84.2 & 80.1 & 88.0 & 0.0 \\
\hline \multirow{2}{*}{$\begin{array}{rr}\text { Exercise intervention timing: } & \text { Before BS } \\
& \text { After BS }\end{array}$} & 4 & 79.4 & 67.7 & 89.4 & 0.0 \\
\hline & 6 & 87.4 & 76.7 & 95.6 & 0.0 \\
\hline \multirow[t]{2}{*}{ Exercise intervention duration: } & 4 & 82.2 & 78.5 & 85.6 & 0.0 \\
\hline & 6 & 86.8 & 71.4 & 97.6 & 27.0 \\
\hline Total compliance rate - exercise intervention & 3 & \multicolumn{4}{|c|}{ No meta-analysis performed } \\
\hline Total dropout rate $(\%)$ - exercise intervention & 19 & 5.0 & 1.1 & $\mathbf{1 0 . 5}$ & 60.1 \\
\hline \multirow[t]{2}{*}{ Study quality: } & 11 & 5.1 & 0.6 & 12.4 & 61.6 \\
\hline & 8 & 5.5 & 0.0 & 18.4 & 58.7 \\
\hline \multirow[t]{2}{*}{ Exercise intervention timing: $\mathrm{F}$} & 7 & 3.6 & 0.0 & 14.6 & 44.4 \\
\hline & 12 & 5.6 & 0.6 & 13.8 & 68.5 \\
\hline \multirow[t]{2}{*}{ Exercise intervention duration: } & 9 & 3.7 & 0.0 & 12.6 & 64.7 \\
\hline & 10 & 6.2 & 0.5 & 15.8 & 56.3 \\
\hline Total dropout rate (\%) control/comparison groups & 18 & 1.6 & $\mathbf{0 . 0}$ & 5.3 & 53.2 \\
\hline \multirow[t]{2}{*}{ Study quality: } & 11 & 2.2 & 0.0 & 7.1 & 60.5 \\
\hline & 7 & 1.9 & 0.0 & 13.3 & 41.4 \\
\hline \multirow[t]{2}{*}{ Exercise intervention timing: $\mathrm{B}$} & 4 & 0.0 & 0.0 & 0.3 & 0.0 \\
\hline & 14 & 2.8 & 0.0 & 8.2 & 62.3 \\
\hline \multirow[t]{2}{*}{ Exercise intervention duration: } & 9 & 0.0 & 0.0 & 2.4 & 6.7 \\
\hline & 8 & 2.9 & 0.0 & 13.1 & 48.3 \\
\hline
\end{tabular}

\section{Feasibility and acceptability of controlled trial methods}

\begin{tabular}{cr:|l:l:l:l:l}
\hline Total refusal rate (\%) & & $\mathbf{1 6}$ & $\mathbf{2 2 . 6}$ & $\mathbf{1 0 . 0}$ & $\mathbf{3 8 . 2}$ & $\mathbf{9 4 . 6}$ \\
\hline Study quality: & High & 10 & 22.7 & 10.4 & 38.0 & 89.5 \\
& Low & 6 & 22.9 & 0.0 & 69.2 & 97.5 \\
\hline Exercise intervention timing: & Before BS & 4 & 30.7 & 0.0 & 81.0 & 91.7 \\
& After BS & 12 & 20.3 & 6.5 & 38.7 & 95.3 \\
\hline Exercise intervention duration: & Longer & 7 & 27.2 & 3.6 & 60.3 & 96.8 \\
& Shorter & 9 & 18.9 & 4.7 & 38.7 & 91.0 \\
\hline Total recruitment rate (n/month) & & $\mathbf{1 2}$ & $\mathbf{7 . 1}$ & $\mathbf{3 . 8}$ & $\mathbf{1 1 . 3}$ & $\mathbf{6 0 . 1}$ \\
\hline Study quality: & High & 8 & 6.3 & 3.8 & 9.2 & 0.0 \\
& Low & 4 & 10.2 & 0.1 & 29.4 & 81.3 \\
\hline Exercise intervention timing: & Before BS & 3 & 8.1 & 0.7 & 20.2 & 0.0 \\
& After BS & 9 & 7.0 & 2.9 & 12.4 & 70.4 \\
\hline Exercise intervention duration: & Longer & 4 & 7.9 & 0.0 & 25.6 & 85.3 \\
& Shorter & 8 & 6.5 & 3.3 & 10.5 & 15.7 \\
\hline Total enrollment speed (n/month) & & $\mathbf{1 3}$ & $\mathbf{2 . 5}$ & $\mathbf{1 . 4}$ & $\mathbf{3 . 7}$ & $\mathbf{0 . 0}$ \\
\hline Study quality: & High & 9 & 2.5 & 1.3 & 4.0 & 0.0 \\
& Low & 4 & 2.8 & 0.3 & 6.8 & 0.0 \\
\hline
\end{tabular}




\begin{tabular}{|c|c|c|c|c|c|}
\hline $\begin{array}{rr}\text { Exercise intervention timing: } & \text { Before BS } \\
& \text { After BS }\end{array}$ & $\begin{array}{l}3 \\
10\end{array}$ & $\begin{array}{l}1.1 \\
2.9\end{array}$ & $\begin{array}{l}0.0 \\
1.6\end{array}$ & $\begin{array}{l}6.2 \\
4.4\end{array}$ & $\begin{array}{l}0.0 \\
0.0\end{array}$ \\
\hline \multirow[t]{2}{*}{ Exercise intervention duration: } & 5 & 1.6 & 0.6 & 2.9 & 0.0 \\
\hline & 8 & 3.3 & 1.4 & 5.6 & 0.0 \\
\hline Total enrollment rate (\%) & 18 & 43.3 & 30.0 & 57.2 & 93.6 \\
\hline \multirow[t]{2}{*}{ Study quality: } & 12 & 40.0 & 26.1 & 54.7 & 90.7 \\
\hline & 6 & 50.1 & 14.0 & 86.1 & 96.4 \\
\hline \multirow[t]{2}{*}{ Exercise intervention timing: } & 4 & 17.4 & 0.4 & 46.5 & 74.7 \\
\hline & 14 & 50.8 & 36.4 & 65.2 & 93.1 \\
\hline \multirow[t]{2}{*}{ Exercise intervention duration: } & 9 & 38.1 & 17.1 & 61.4 & 95.7 \\
\hline & 9 & 49.0 & 29.7 & 68.5 & 89.1 \\
\hline Total retention rate $(\%)$ - exercise intervention & 26 & 87.1 & 79.6 & 93.3 & 79.5 \\
\hline \multirow{2}{*}{ Study quality: } & 13 & 92.9 & 84.4 & 98.6 & 78.7 \\
\hline & 13 & 77.2 & 65.7 & 87.3 & 61.3 \\
\hline \multirow[t]{2}{*}{ Exercise intervention timing: } & 7 & 96.4 & 84.6 & 100 & 49.5 \\
\hline & 19 & 83.6 & 74.1 & 91.5 & 82.8 \\
\hline \multirow{2}{*}{ Exercise intervention duration: } & 12 & 86.8 & 75.5 & 95.5 & 77.1 \\
\hline & 13 & 84.3 & 72.1 & 93.9 & 70.8 \\
\hline Total retention rate (\%) - control/comparison groups & 26 & 86.8 & 80.6 & 92.1 & 65.5 \\
\hline \multirow[t]{2}{*}{ Study quality: } & 13 & 88.9 & 81.2 & 95.1 & 67.7 \\
\hline & 13 & 82.8 & 71.7 & 92.0 & 50.7 \\
\hline \multirow{2}{*}{$\begin{array}{rr}\text { Exercise intervention timing: } & \text { Before BS } \\
& \text { After BS } \\
\end{array}$} & 6 & 89.5 & 77.8 & 97.8 & 0.0 \\
\hline & 20 & 85.7 & 78.1 & 92.1 & 72.9 \\
\hline \multirow[t]{2}{*}{ Exercise intervention duration: } & 12 & 90.4 & 62.8 & 95.7 & 75.1 \\
\hline & 13 & 81.7 & 72.5 & 89.6 & 32.0 \\
\hline
\end{tabular}




\begin{tabular}{|c|c|c|c|c|c|c|c|c|}
\hline $\begin{array}{l}\text { Author Year } \\
\text { (Country) } \\
\text { Study design }\end{array}$ & $\begin{array}{l}\text { Study duration } \\
\text { for one } \\
\text { participant } \\
\text { Timing of } \\
\text { assessment and } \\
\text { indenisation }\end{array}$ & Outcomes assessed* & $\begin{array}{l}\text { Recruitment } \\
\text { duration, } \\
\text { strategies and } \\
\text { timing }\end{array}$ & $\begin{array}{l}\text { Recruit } \\
\text { ment } \\
\text { rate } \\
\text { (number/ } \\
\text { mo.) }\end{array}$ & $\begin{array}{l}\text { Refusal rate }(\%) \\
\text { Reasons to decline to } \\
\text { participate }\end{array}$ & $\begin{array}{l}\text { Enrollment } \\
\text { speed } \\
\text { (participant } \\
\text { number/mo.) } \\
\text { Enrollment } \\
\text { rate }(\%)\end{array}$ & $\begin{array}{l}\text { Retention rate }(\%) \\
\text { Reasons for the lost of follow-up }\end{array}$ & $\begin{array}{l}\text { Randomization refusal } \\
\text { rate }(\%) \\
\text { Reasons to decline } \\
\text { randomization }\end{array}$ \\
\hline \multicolumn{9}{|c|}{ Studies with intervention delivered before BS } \\
\hline $\begin{array}{l}\text { Funderburk } \\
2010 \\
\text { (USA) } \\
\text { Pilot RCT }\end{array}$ & $\begin{array}{l}\text { 13 wk. } \\
\text { Pre and post } \\
\text { intervention } \\
\quad N A\end{array}$ & $\begin{array}{l}\text { 1. Weight }{ }^{\mathrm{O}} \\
\text { 2. Quality of life } \mathrm{S} \\
\text { 3.Psychological distress } \\
\text { 4. Depression } \\
\text { S } \\
\text { 5. Blood pressure } \\
\text { 6. Physical fitness }\end{array}$ & $\begin{array}{l}\text { NA } \\
\text { Active } \\
\text { Before BS }\end{array}$ & NA & NA & NA & NA & NA \\
\hline $\begin{array}{l}\text { Baillot } 2016 \\
\text { (Canada) } \\
\text { RCT }\end{array}$ & $\begin{array}{l}\sim 12 \text { wk. }+52 \\
\text { wk. f-up } \\
\\
\text { Pre and post } \\
\text { intervention } \\
+4 x \text { during f-up } \\
\quad \text { No }\end{array}$ & $\begin{array}{l}\text { 1. Anthropometry } \\
\text { 2. Body composition } \\
\text { 3. Blood pressure } \\
\text { 4. Physical fitness } \\
\text { 5. } \mathrm{PA}^{\mathrm{S}} \\
\text { 6. Quality of life } \mathrm{S} \\
\text { 7. Satisfaction }\end{array}$ & $\begin{array}{l}23 \text { months } \\
\begin{array}{l}\text { Active and } \\
\text { passive }\end{array} \\
\text { Before BS }\end{array}$ & 6.1 & $\begin{array}{l}18.9 \% \\
\text { Reasons: } \\
\text { No research interest }(\mathrm{n}=5) \\
\text { Did not like group } \\
\text { exercise }(\mathrm{n}=2)\end{array}$ & $\begin{array}{l}1.3 \\
21.4 \%\end{array}$ & $\begin{array}{l}\text { For intervention part: } \\
\text { Exercise group: } 100 \% \\
\text { Control group: } 93 \% \\
\text { Reason: } \\
\text { Disagree with her allocation }(\mathrm{n}=1) \\
\text { For f-up part: } \\
\text { Exercise group: } 93 \% \\
\text { Reasons: } \\
\text { No surgery (cancer) }(\mathrm{n}=1) \\
\text { Control group: } 93 \% \\
\text { Reasons: } \\
\text { Abandonment }(\mathrm{n}=1) \\
\end{array}$ & $\begin{array}{l}\text { Exercise group: } 0 \% \\
\text { Control group: } 6.7 \% \\
\text { Reason: } \\
\text { Want to be in exercise group } \\
(\mathrm{n}=1)\end{array}$ \\
\hline $\begin{array}{c}\text { Marcon } \\
2017 \\
\text { (Brazil) } \\
\text { RCT }\end{array}$ & $\begin{array}{l}\sim 19 \text { wk. } \\
\text { Pre and post } \\
\text { intervention } \\
\quad N A\end{array}$ & $\begin{array}{l}\text { 1. Anthropometry } \\
\text { 2. Functional capacity } \\
\text { 3. Physical fitness } \\
\text { 4. Cardiovascular risk } \\
\text { 5. Lipid profile }\end{array}$ & $\begin{array}{l}\text { NA } \\
\text { Active } \\
\text { Before BS }\end{array}$ & NA & $\begin{array}{l}7.0 \% \\
\text { Reason: NA }\end{array}$ & $\begin{array}{l}\text { NA } \\
13.4 \%\end{array}$ & $\begin{array}{l}\text { Exercise group: } 100 \% \\
\text { Exercise group + CBT: } 77 \% \\
\text { Reasons: } \\
\text { Surgery was anticipated }(\mathrm{n}=1) \\
\text { Unable to attend intervention }(\mathrm{n}=1) \\
\text { Control group: } 82 \% \\
\text { Reasons: } \\
\text { Changed address }(\mathrm{n}=1) \\
\text { Did not attend the assessment }(\mathrm{n}=3)\end{array}$ & $\begin{array}{l}\text { Exercise group: } 0 \% \\
\text { Exercise group + CBT: } 0 \% \\
\text { Control group: } 0 \%\end{array}$ \\
\hline
\end{tabular}




\begin{tabular}{|c|c|c|c|c|c|c|c|c|}
\hline $\begin{array}{l}\text { Picó-Sirvent } \\
2019 \\
\text { (Spain) } \\
\text { Pilot QE }\end{array}$ & $\begin{array}{l}\sim 26 \mathrm{wk} . \\
\text { Pre, mid and } \\
\text { post } \\
\text { intervention } \\
\text { NA }\end{array}$ & $\begin{array}{l}\text { 1. Anthrometry } \\
\text { 2. Body composition } \mathrm{O} \\
\text { 3. Cardiometabolic risk } \\
\text { factors }{ }^{\mathrm{O}} \\
\text { 4.Physical fitness }\end{array}$ & $\begin{array}{l}\text { NA } \\
\text { Active } \\
\text { Before BS }\end{array}$ & NA & NA & NA & Control group: $100 \%$ & Not applicable \\
\hline $\begin{array}{l}\text { Marc- } \\
\text { Hernández } \\
2019 \\
\text { (Spain) } \\
\text { QE }\end{array}$ & $\begin{array}{l}\sim 12 \text { wk. } \\
\text { Pre and post } \\
\text { intervention } \\
\quad N A\end{array}$ & $\begin{array}{l}\text { 1. Anthopometry } \\
\text { 2. Body composition } \\
\text { 3. } \text { REE }^{\mathrm{O}} \\
\text { 4. Cardiometabolic risk } \\
\text { factors } \mathrm{O} \\
\text { 5. Physical fitness } \\
\text { 6. Quality of life } \\
\end{array}$ & $\begin{array}{l}\text { NA } \\
\text { Active } \\
\text { Before BS }\end{array}$ & NA & $\begin{array}{l}\text { NA } \\
\text { Reason: NA }\end{array}$ & $\begin{array}{l}\text { NA } \\
\text { NA }\end{array}$ & $\begin{array}{l}\text { Exercise group: } 83 \% \\
\text { Reasons: } \\
\text { Left the program }(\mathrm{n}=1) \\
\text { Experienced physical problems }(\mathrm{n}=1) \\
\text { Control group: } 73 \% \\
\text { Reason: NA }\end{array}$ & Not applicable \\
\hline $\begin{array}{l}\text { Gilbertson } \\
2020 \\
\text { (USA) } \\
\text { Pilot QE }\end{array}$ & $\begin{array}{l}\quad \sim 4 \text { wk. } \\
\text { Pre and post } \\
\text { intervention } \\
\quad N A\end{array}$ & $\begin{array}{l}\text { 1. Body composition } \\
\text { 2. Physical fitness } \\
\text { 3. Food diary } \\
\text { S } \\
\text { 4. MMTT } \\
\text { 5. Surgical outcomes } \\
\text { 6. Adipose tissue gene } \\
\text { expression of adiponectin } \\
\text { and leptin } \\
\end{array}$ & $\begin{array}{l}38 \text { months } \\
\text { Active and } \\
\text { passive } \\
\text { Before BS }\end{array}$ & 13.8 & $\begin{array}{l}73.0 \% \\
\text { Reason: NA }\end{array}$ & $\begin{array}{l}0.4 \\
3.2 \%\end{array}$ & $\begin{array}{l}\text { Exercise group: } 90 \% \\
\text { Reason: } \\
\text { Discontinue intervention }(\mathrm{n}=1) \\
\text { Control group: } 100 \%\end{array}$ & Not applicable \\
\hline $\begin{array}{c}\text { Arman } 2021 \\
\text { (Turkey) } \\
\text { RCT }\end{array}$ & $\begin{array}{l}\sim 8 \mathrm{wk} . \\
\text { Pre and post } \\
\text { intervention } \\
\quad N A\end{array}$ & $\begin{array}{l}\text { 1. Body composition } \\
\text { 2. Functional capacity } \\
\text { 3. Physical fitness } \\
\text { 4. Fatigue } \\
\text { 5. Quality of life } \\
\text { 5 }\end{array}$ & $\begin{array}{l}6 \text { months } \\
\text { Active } \\
\text { Before BS }\end{array}$ & 9.3 & $\begin{array}{l}39.5 \% \\
\text { Reason: NA }\end{array}$ & $\begin{array}{l}3.8 \\
41.1 \%\end{array}$ & $\begin{array}{l}\text { Exercise group: } 100 \% \\
\text { Control group: } 85 \% \\
\text { Reasons: } \\
\text { Sedentary behaviors }(\mathrm{n}=1) \\
\text { Transportation problem }(\mathrm{n}=1) \\
\end{array}$ & $\begin{array}{l}\text { Exercise group: } 0 \% \\
\text { Control group: } 0 \%\end{array}$ \\
\hline \multicolumn{9}{|c|}{ Studies with intervention after bariatric surgery } \\
\hline $\begin{array}{l}\text { Castello } 2011 \\
\text { (Brazil) } \\
\text { RCT }\end{array}$ & $\begin{array}{l}\sim 17 \text { wk. } \\
\text { Pre BS and post } \\
\text { intervention } \\
\text { NA }\end{array}$ & $\begin{array}{l}\text { 1. Anthropometry } \\
\text { 2. Body composition } \\
\text { 3. Pulmonary function } \\
\text { 4. Lipid profile } \\
\text { 5. Heart rate variability } \\
\text { 6. Physical fitness } \\
\text { 7. Functional capacity }\end{array}$ & $\begin{array}{l}24 \text { months } \\
\text { Active } \\
\text { Before BS }\end{array}$ & 2.2 & $\begin{array}{l}13.5 \% \\
\text { Reason: } \\
\text { Did not consent }(n=5)\end{array}$ & $\begin{array}{l}1,3 \\
61.5 \%\end{array}$ & $\begin{array}{l}\text { Exercise group: } 69 \% \\
\text { Reasons: } \\
\text { Did not like to exercise due } \\
\text { muscle or joint pain }(\mathrm{n}=2) \\
\text { Trouble balance life and exercise } \\
(\mathrm{n}=3) \\
\text { Control group: } 63 \% \\
\text { Reason: } \\
\text { No time to exercise }(\mathrm{n}=6)\end{array}$ & $\begin{array}{l}\text { Exercise group: } 0 \% \\
\text { Control group: } 0 \%\end{array}$ \\
\hline $\begin{array}{l}\text { Shah } 2011 \\
\text { (USA) } \\
\text { RCT }\end{array}$ & $\begin{array}{l}\sim 12 \mathrm{wk} . \\
\text { Pre, middle and } \\
\text { post }\end{array}$ & $\begin{array}{l}\text { 1. Anthropometry } \\
\text { 2. Body composition } \\
\text { 3. } \text { PA }^{\mathrm{O}} \\
\text { 4. Physical fitness }\end{array}$ & NA & NA & NA & NA & $\begin{array}{l}\text { Exercise group: } 76 \% \\
\text { Reasons: } \\
\text { No time to exercise }(n=5) \\
\text { Control group: } 67 \%\end{array}$ & $\begin{array}{l}\text { Exercise group: } 0 \% \\
\text { Control group: } 25 \% \\
\text { Reason: }\end{array}$ \\
\hline
\end{tabular}




\begin{tabular}{|c|c|c|c|c|c|c|c|c|}
\hline & $\begin{array}{l}\text { intervention } \\
\quad N A\end{array}$ & $\begin{array}{l}\text { 5. } \mathrm{REE}^{\mathrm{O}} \\
\text { 6. Dietary intake } \\
\text { 7. Glucose metabolism } \\
\text { 8. Lipid profile } \mathrm{O} \\
\text { 9. Quality of life } \\
\end{array}$ & After BS & & & & $\begin{array}{l}\text { Reasons: } \\
\text { Would have preferred to be in } \\
\text { exercise group }(\mathrm{n}=3) \\
\text { No time for the study }(\mathrm{n}=1)\end{array}$ & $\begin{array}{l}\text { Want to be in exercise group } \\
(\mathrm{n}=4)\end{array}$ \\
\hline $\begin{array}{l}\text { Stegen } 2011 \\
\text { (Belgium) } \\
\text { Pilot QE }\end{array}$ & $\begin{array}{l}\sim 17 \mathrm{wk} . \\
\text { Pre BS and post } \\
\text { intervention } \\
\text { NA }\end{array}$ & $\begin{array}{l}\text { 1. Anthropometry }{ }^{\mathrm{O}} \\
\text { 2. Body composition } \mathrm{O} \\
\text { 3. Physical fitness } \\
\text { 4. Functional capacity }\end{array}$ & $\begin{array}{l}\text { NA } \\
\text { NA } \\
\text { Before BS }\end{array}$ & NA & NA & NA & $\begin{array}{l}\text { Exercise group: } 80 \% \\
\text { Reasons: } \\
\text { Demanding job, household, or } \\
\text { education (n=NA) } \\
\text { Control group: } 78 \% \\
\text { Reasons: } \\
\text { Demanding job, household, or } \\
\text { education(n=NA) }\end{array}$ & Not applicable \\
\hline $\begin{array}{l}\text { Coen } 2015 \\
\text { (USA) } \\
\text { RCT }\end{array}$ & $\begin{array}{l}\sim 26 \mathrm{wk} . \\
\text { Pre and post } \\
\text { intervention } \\
200 \$ \times 2 \text { visits }\end{array}$ & $\begin{array}{l}\text { 1. Anthropometry }{ }^{\mathrm{O}} \\
\text { 2. Body composition } \\
\text { 3. Glucose metabolism } \\
\text { 4. Physical fitness } \\
\text { O } \\
\text { 5. Blood pressure } \\
\text { 6. Plasma lipids } \\
\text { 7. Hepatic enzymes }\end{array}$ & $\begin{array}{l}43 \text { months } \\
\text { NA } \\
\text { After BS }\end{array}$ & 8.7 & NA & 3,0 & $\begin{array}{l}\text { Exercise group: } 91 \% \\
\text { Reasons: } \\
\text { Commitment issues }(\mathrm{n}=5) \\
\text { Lost to follow up }(\mathrm{n}=1) \\
\text { Control group: } 95 \% \\
\text { Reasons: } \\
\text { Move in another city }(\mathrm{n}=1) \\
\text { Pregnancy }(\mathrm{n}=1) \\
\text { Lost to follow up }(\mathrm{n}=1)\end{array}$ & $\begin{array}{l}\text { Exercise group: } 0 \% \\
\text { Control group: } 0 \%\end{array}$ \\
\hline $\begin{array}{l}\text { Huck } 2015 \\
\text { (USA) } \\
\text { Pilot QE }\end{array}$ & $\begin{array}{l}\sim 12 \mathrm{wk} . \\
\text { Pre and post } \\
\text { intervention } \\
\quad N A\end{array}$ & $\begin{array}{l}\text { 1. Anthropometry } \\
\text { 2. Body composition } \\
\text { 3. Heart rate } \\
\text { 5. Blood pressure } \\
\text { 6. Functional capacity } \\
\text { 7. Physical fitness }{ }^{\mathrm{O}}\end{array}$ & $\begin{array}{l}\text { NA } \\
\text { Passive } \\
\text { After BS }\end{array}$ & NA & NA & NA & $\begin{array}{l}\text { Exercise group: NA } \\
\text { Reason: } \\
\text { Economic and personal issues }(\mathrm{n}=2) \\
\text { Control group: NA }\end{array}$ & Not applicable \\
\hline $\begin{array}{l}\text { Marchesi } \\
2015 \\
\text { (Italy) } \\
\text { Pilot QE }\end{array}$ & $\begin{array}{l}\sim 44 \mathrm{wk} . \\
\text { Pre, middle and } \\
\text { post } \\
\text { intervention } \\
N A\end{array}$ & $\begin{array}{l}\text { 1. Anthropometry }{ }^{\mathrm{O}} \\
\text { 2. Body composition } \\
\text { 3. Physical fitness }{ }^{\mathrm{O}} \\
\text { 4. Cardiological } \\
\text { assessment } \\
\text { 5. Heart rate variability } \\
\text { 6. Psychiatric } \\
\text { assessments } \\
\text { 7. Blood and urinary } \\
\text { metabolic parameters }\end{array}$ & $\begin{array}{l}\text { NA } \\
\text { Active }\end{array}$ & NA & NA & NA & $\begin{array}{l}\text { Exercise group: } 70 \% \\
\text { Reason: } \\
\text { Motivation problem (n=3) } \\
\text { Control group: } 100 \%\end{array}$ & Not applicable \\
\hline
\end{tabular}




\begin{tabular}{|c|c|c|c|c|c|c|c|c|}
\hline $\begin{array}{l}\text { Muschitz } \\
2016 \\
\text { (Austria) } \\
\text { RCT }\end{array}$ & $\begin{array}{l}\sim 113 \text { wk. } \\
\text { Pre BS and } \\
\text { middle-post } \\
\text { intervention } \\
\quad(9 x) \\
\text { NA }\end{array}$ & $\begin{array}{l}\text { 1. Anthropometry } \\
\text { 2. Bone metabolism } \\
\text { 3. Bone mineral density } \\
\text { 4. Quality of life } \mathrm{e}^{\mathrm{S}}\end{array}$ & $\begin{array}{l}\text { NA } \\
\text { NA } \\
\text { Before BS }\end{array}$ & NA & NA & $\begin{array}{l}\text { NA } \\
\text { NA }\end{array}$ & $\begin{array}{l}\text { Exercise group: } 100 \% \\
\text { Control group: } 85 \% \\
\text { Reasons: } \\
\text { Unwilling to stay within the study } \\
(\mathrm{n}=12) \\
\text { Move outside Vienna }(\mathrm{n}=4)\end{array}$ & $\begin{array}{l}\text { Exercise group: } 0 \% \\
\text { Control group: } 0 \%\end{array}$ \\
\hline $\begin{array}{l}\text { Rojhani- } \\
\text { Shirazi } 2016 \\
\text { (Iran) } \\
\text { RCT }\end{array}$ & $\begin{array}{l}\sim 4 \mathrm{wk} . \\
\text { Pre BS and post } \\
\text { intervention } \\
\text { NA }\end{array}$ & $\begin{array}{l}\text { 1. Anthropometry } \\
\text { 2. Balance }\end{array}$ & $\begin{array}{l}\text { NA } \\
\text { NA } \\
\text { Before BS }\end{array}$ & NA & NA & NA & NA & NA \\
\hline $\begin{array}{l}\text { Campanha- } \\
\text { Versiani } \\
2017 \\
\text { (Brazil) } \\
\text { QE }\end{array}$ & $\begin{array}{l}\sim 52 \text { wk. } \\
\text { Pre BS and pre } \\
\text { middle-post } \\
\text { intervention } \\
(5 x) \\
N A\end{array}$ & $\begin{array}{l}\text { 1. Anthropometry } \\
\text { 2. Strength } \\
\text { 3. Bone } \\
\text { metabolism } \\
\end{array}$ & $\begin{array}{l}\text { NA } \\
\text { NA } \\
\text { Before BS }\end{array}$ & NA & $\begin{array}{l}11.8 \% \\
\text { Reason: NA }\end{array}$ & $\begin{array}{l}\text { NA } \\
84.5 \%\end{array}$ & $\begin{array}{l}\text { Exercise group: } 60 \% \\
\text { Reasons: } \\
\text { Began climacteric period }(n=1) \\
\text { Post-operative complications }(n=2) \\
\text { Study dropped }(n=9) \\
\text { Control group: } 63 \% \\
\text { Reasons: } \\
\text { Began climacteric period }(n=1) \\
\text { Post-operative complications }(n=2) \\
\text { Study dropped }(n=8)\end{array}$ & Not applicable \\
\hline $\begin{array}{l}\text { Coleman } \\
2017 \\
\text { (USA) } \\
\text { Pilot RCT }\end{array}$ & $\begin{array}{l}52 \mathrm{wk} . \\
\text { Pre, } \text { middle and } \\
\text { post } \\
\text { intervention } \\
25 \$ x 3 \text { visits }+ \\
25 \$ / \text { pedometer } \\
\text { return }\end{array}$ & $\begin{array}{l}\text { 1. Anthrometry } \\
\text { 2. } \mathrm{PA}^{\mathrm{O}} \\
\text { 3. Functional capacity } \\
\text { 4. Sedentary activity, } \\
\text { aerobic exercise, } \\
\text { flexibility et muscle } \\
\text { strength }^{\mathrm{S}}\end{array}$ & $\begin{array}{l}\text { NA } \\
\text { Active } \\
\text { After BS }\end{array}$ & NA & NA & $\begin{array}{l}\text { NA } \\
33.6 \%\end{array}$ & $\begin{array}{l}\text { Exercise group: } 81 \% \\
\text { Reasons: } \\
\text { Do not respond }(\mathrm{n}=3) \\
\text { Dropout during intervention }(\mathrm{n}=2) \\
\text { Control group: } 92 \% \\
\text { Reason: } \\
\text { Do not respond }(\mathrm{n}=3)\end{array}$ & $\begin{array}{l}\text { Exercise group: } 0 \% \\
\text { Control group: } 0 \%\end{array}$ \\
\hline $\begin{array}{l}\text { Herring } \\
2017 \\
\text { (UK) } \\
\text { RCT }\end{array}$ & $\begin{array}{l}\sim 12 \text { wk. }+12 \\
\text { wk. of f-up } \\
\\
\text { Pre and post } \\
\text { intervention }+f \text { - } \\
\text { up } \\
\text { NA }\end{array}$ & $\begin{array}{l}\text { 1. Anthropometry } \\
\text { 2. Physical fitness } \\
\text { 3. Cardiovascular } \\
\text { measurements } \\
\text { 4. } \mathrm{PA}^{\mathrm{O}}\end{array}$ & $\begin{array}{l}13 \text { months } \\
\text { Active } \\
\text { After BS }\end{array}$ & 3.6 & $\begin{array}{l}20 \% \\
\text { Reasons: } \\
\text { Work commitments }(n=3) \\
\text { Illnesses preventing } \\
\text { exercise }(n=2) \\
\text { No surgery }(n=2) \\
\text { No reason given }(n=3)\end{array}$ & $\begin{array}{l}1.8 \% \\
51.1 \%\end{array}$ & $\begin{array}{l}\text { Exercise group: } 92 \% \\
\text { Reasons: } \\
\text { Had a gastric bad deflated }(\mathrm{n}=1) \\
\text { Control group: } 83 \% \\
\text { Reason: } \\
\text { Want exercise group }(\mathrm{n}=2) \\
\text { For f-up part: No lost to f-up }\end{array}$ & $\begin{array}{l}\text { Exercise group: } 0 \% \\
\text { Control group: } 8.3 \% \\
\text { Reason: } \\
\text { Want exercise group }\end{array}$ \\
\hline
\end{tabular}




\begin{tabular}{|c|c|c|c|c|c|c|c|c|}
\hline $\begin{array}{l}\text { Onofre 2017 } \\
\text { (Brazil) } \\
\text { Pilot QE }\end{array}$ & $\begin{array}{l}\sim 26 \text { wk. } \\
\text { Pre BS, pre and } \\
\text { post } \\
\text { intervention } \\
N A \\
\end{array}$ & $\begin{array}{l}\text { 1. Anthropometry } \\
\text { 2. Body composition } \\
\text { 3. Pulmonary function } \\
\text { 4. Physical fitness }\end{array}$ & $\begin{array}{l}\text { NA } \\
\text { NA } \\
\text { Before BS }\end{array}$ & NA & $0 \%$ & $\begin{array}{l}\text { NA } \\
63.2 \%\end{array}$ & $\begin{array}{l}\text { Exercise group: } 100 \% \\
\text { Control group: } 100 \%\end{array}$ & Not applicable \\
\hline $\begin{array}{c}\text { Daniels } \\
2017 \\
\text { (USA) } \\
\text { RCT } \\
\end{array}$ & $\begin{array}{l}\sim 12 \mathrm{wk} . \\
\text { PreBS and post } \\
\text { intervention } \\
\text { NA }\end{array}$ & $\begin{array}{l}\text { 1. Anthropometry } \mathrm{O} \\
\text { 2. Body composition } \mathrm{O} \\
\text { 3. Physical fitness }\end{array}$ & $\begin{array}{l}\text { NA } \\
\text { Passive } \\
\text { Before BS }\end{array}$ & NA & NA & $\begin{array}{l}\text { NA } \\
\text { NA }\end{array}$ & $\begin{array}{l}\text { Exercise group: } 100 \% \\
\text { Control group: } 100 \%\end{array}$ & $\begin{array}{l}\text { Exercise group: } 0 \% \\
\text { Control group: } 0 \%\end{array}$ \\
\hline $\begin{array}{l}\text { Hassannejad } \\
2017 \\
\text { (Iran) } \\
\\
\text { RCT } \\
\end{array}$ & $\begin{array}{l}\sim 12 \mathrm{wk} . \\
\text { Pre BS and post } \\
\text { intervention } \\
\text { NA }\end{array}$ & $\begin{array}{l}\text { 1.Anthropometry } \\
\text { 2. Body composition } \\
\text { 3. Physical fitness } \\
\text { O } \\
\text { 4. } \text { PA }^{\mathrm{S}} \\
\text { 5. Dietary Intake } \\
\end{array}$ & $\begin{array}{l}8 \text { months } \\
\text { Active } \\
\text { Before BS }\end{array}$ & 11.8 & $\begin{array}{l}27.7 \% \\
\text { Reason: NA }\end{array}$ & $\begin{array}{l}7.5 \\
63.8 \%\end{array}$ & NA & Three groups: $0 \%$ \\
\hline $\begin{array}{l}\text { Mundbjerg } \\
2018 \\
\text { (Denmark) } \\
\text { RCT }\end{array}$ & $\begin{array}{c}\sim 52 \text { wk. }+52 \\
\text { wk. f-up } \\
\text { Pre BS, pre and } \\
\text { post } \\
\text { intervention }+f \text { - } \\
\text { up } \\
\text { NA }\end{array}$ & $\begin{array}{l}\text { 1. Anthropometry } \\
\text { 2. Body composition } \\
\text { 3. Blood pressure and } \\
\text { heart rate }{ }^{\mathrm{O}} \\
\text { 4. Glucose and lipid } \\
\text { metabolism }^{\mathrm{O}}\end{array}$ & $\begin{array}{l}25 \text { months } \\
\text { NA } \\
\text { Before BS }\end{array}$ & 2.8 & $\begin{array}{l}4.8 \% \\
\text { Reason: NA }\end{array}$ & $\begin{array}{l}2.4 \\
85.7 \%\end{array}$ & $\begin{array}{l}\text { For intervention part: } \\
\text { Exercise group: } 84 \% \\
\text { Reasons: } \\
\text { Pregnancy ( } \mathrm{n}=1) \\
\text { Declined to participate }(\mathrm{n}=4) \\
\text { Control group: } 89 \% \\
\text { Reasons: } \\
\text { Pregnancy ( } \mathrm{n}=1) \\
\text { Declined to participate }(\mathrm{n}=2) \\
\text { For f-up part: } \\
\text { Exercise group: } 82 \% \\
\text { Reasons: } \\
\text { Pregnancy ( } \mathrm{n}=1) ; \text { Injury }(\mathrm{n}=1) \\
\text { Declined to participate }(\mathrm{n}=3) \\
\text { Control group: } 80 \% \\
\text { Reasons: } \\
\text { Pregnancy ( } \mathrm{n}=2) \\
\text { Declined to participate }(\mathrm{n}=3)\end{array}$ & $\begin{array}{l}\text { Exercise group: } 0 \% \\
\text { Control group: } 0 \%\end{array}$ \\
\hline $\begin{array}{c}\text { Oppert } 2018 \\
\text { (France) } \\
\text { RCT }\end{array}$ & $\begin{array}{l}\sim 24 \text { wk. } \\
\text { PreBS and 1,3, } \\
6 \text { months after } \\
\text { surgery }(4 x) \\
\text { NA }\end{array}$ & $\begin{array}{l}\text { 1. Anthropometry } \\
\text { 2. Body composition } \\
\text { 3. Physical fitness } \\
\text { 4. } \\
\text { 4A } \\
\text { 5. Quality of life } \\
\text { 6. Food and beverage } \\
\text { consumption }\end{array}$ & $\begin{array}{l}56 \text { months } \\
\text { Active } \\
\text { Before BS }\end{array}$ & 5.2 & $\begin{array}{l}62.2 \% \\
\text { Reason: NA }\end{array}$ & $\begin{array}{l}1.4 \\
26.2 \%\end{array}$ & $\begin{array}{l}\text { Exercise + Protein group: } 100 \% \\
\text { Protein group: } 100 \% \\
\text { Control group: } 100 \%\end{array}$ & Three groups: $0 \%$ \\
\hline
\end{tabular}


7. Metabolic parameters

and vitamins ${ }^{\mathrm{O}}$

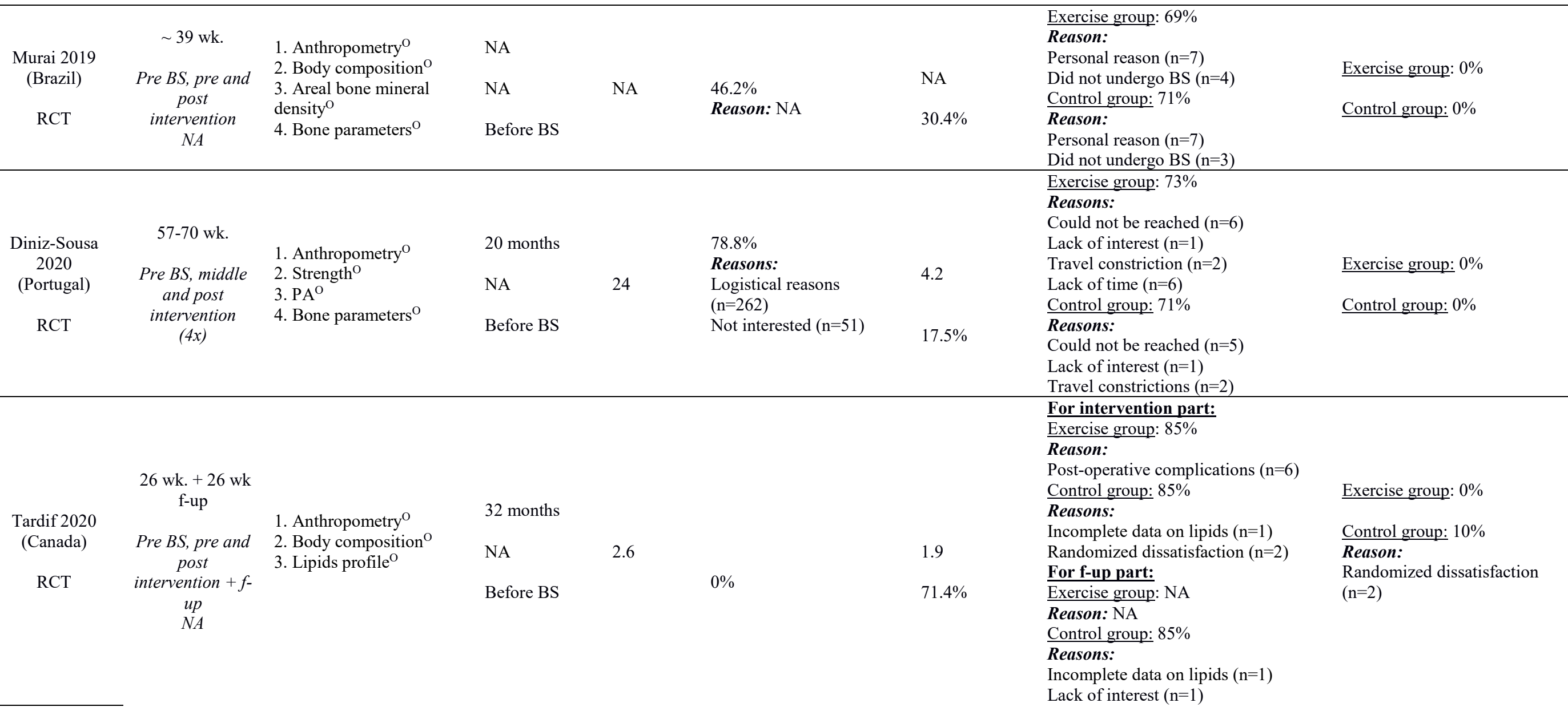




\begin{tabular}{|c|c|c|c|c|c|c|c|c|}
\hline $\begin{array}{l}\text { Marc- } \\
\text { Hernández } \\
2020 \\
\text { (Spain) } \\
\\
\text { RCT }\end{array}$ & $\begin{array}{c}161 \text { wk. before } \\
\text { intervention }+ \\
22 \text { wk. }+9 \text { wk. } \\
\text { f-up for exercise } \\
\text { group } \\
\text { 5x before } \\
\text { intervention }+ \\
\text { post } \\
\text { intervention }+f- \\
\text { up } \\
N A\end{array}$ & $\begin{array}{l}\text { 1. Anthropometry } \\
\text { 2. Body composition } \\
\text { 3. Physical fitness } \\
\text { 4. Cardio-metabolic risk } \\
\text { factors } \\
\text { 5. Quality of life }\end{array}$ & $\begin{array}{l}36 \text { months } \\
\text { Active } \\
\text { Before BS }\end{array}$ & NA & $\begin{array}{l}5.0 \% \\
\text { Reason: NA }\end{array}$ & $\begin{array}{l}1.1 \\
21.1 \%\end{array}$ & $\begin{array}{l}\text { Exercise group: } 100 \% \\
\text { For f-up part: No lost to f-up } \\
\text { Control group: } 80 \% \\
\text { Reason: } \\
\text { Refused to continue }(\mathrm{n}=2)\end{array}$ & $\begin{array}{l}\text { Exercise group: } 0 \% \\
\text { Control group: } 0 \%\end{array}$ \\
\hline $\begin{array}{c}\text { Lamarca } \\
2021 \\
\text { (Brazil) } \\
\text { QE }\end{array}$ & $\begin{array}{l}\sim 12 \text { wk. } \\
\text { Pre and post } \\
\text { intervention } \\
\text { (middle for food } \\
\text { intake) } 3 x \\
\text { NA }\end{array}$ & $\begin{array}{l}\text { 1. Anthropometry } \mathrm{O} \\
\text { 2. Body composition } \\
\text { 3. } \text { REE }^{\mathrm{O}} \\
\text { 4. Blood parameters } \\
\text { 5. Dietary intake }\end{array}$ & $\begin{array}{l}18 \text { months } \\
\text { Passive } \\
\text { After BS }\end{array}$ & 10.0 & $\begin{array}{l}16.2 \% \\
\text { Reason: NA }\end{array}$ & $\begin{array}{l}6.6 \\
66.1 \%\end{array}$ & $\begin{array}{l}\text { Exercise group + Protein: } 56 \% \\
\text { Reasons: } \\
\text { Pregnancy }(\mathrm{n}=1) \\
\text { External accident } / \text { illness }(\mathrm{n}=1) \\
\text { External exercise training }(\mathrm{n}=1) \\
\text { Declined ( } \mathrm{n}=9) \\
\text { Exercise group: } 47 \% \\
\text { Reason: } \\
\text { External accident } / \text { illness }(\mathrm{n}=5) \\
\text { Declined }(\mathrm{n}=13) \\
\text { Protein group: } 63 \% \\
\text { Reasons: } \\
\text { External accident } \mathrm{i} \text { illness }(\mathrm{n}=2) \\
\text { Performed a dermolipectomy }(\mathrm{n}=1) \\
\text { Declined }(\mathrm{n}=9) \\
\text { Placebo group: } 77 \% \\
\text { Reasons: } \\
\text { Performed a dermolipectomy }(\mathrm{n}=1) \\
\text { External accident } / \text { illness }(\mathrm{n}=1) \\
\text { Non-specific edema }(\mathrm{n}=1) \\
\text { Declined }(\mathrm{n}=3)\end{array}$ & Not applicable \\
\hline
\end{tabular}

